\title{
SOCIAL AND ENVIRONMENTAL PROTECTION IN BILATERAL INVESTMENT TREATIES: FOREIGN INVESTORS' PERSPECTIVE
}

\author{
M. Aji Satria . $^{1}$
}

\begin{abstract}
The limit of host states' right to regulate foreign investment within their jurisdiction has been the main, yet unresolved issues in international investment law. This makes it more difficult, given the global structure of investment law that consists of networks of Bilateral Investment Treaties (BITs). This article will not deal with the question of optimal structure of regulatory discretion under BITs which is still debatable among scholars. The central agenda of this article is to address the precondition for an efficient outcome to materialize within the complex web of BITs already signed among states. It is even more complex to be concluded. This issue is due to the absence of international coordinating institution, letting alone that of global supranational authority. This is different from the case of domestic regulatory takings which "simply" requires the correct information and measure from the benevolent government, that means, the existence of an efficient provision, if any, will not necessarily result in an efficient outcome. The main research question addressed in the article is: under what condition a capital exporting state could introduce higher flexibility for regulating public interest in an investment treaty negotiation? The article offer the answer on issue linkage between the level of protection under BIT, the degree of openness of access to domestic legal and regulatory making of the host state, and the foreign investor's capabilities to deal with the trade-off. Ceteris paribus, the linkage enables a set of feasible Pareto improving deals out of BIT negotiation
\end{abstract}

\section{Introduction}

The limit of host states' right to regulate foreign investment within their jurisdiction has been the main, yet unresolved issues in international investment law. ${ }^{2}$ Under a standard investment treaty, regulatory measures to protect or promote social and environmental objectives, that diminish the value of foreign investments, could be deemed as regulatory expropriation; pursuant to which the host state is required to pay for compensation to the foreign investor under the shadow of direct investor-state arbitration. The solution for this problem mainly calls for the introduction of broader provision in international investment

${ }^{1}$ Assistant Lecturer at Faculty of Law University of Indonesia

${ }^{2}$ Various literatures offer different forms of solutions to this problem. See for example Eric Neumayer, Greening Trade and Investment: Environmental Protection without Protectionism, (Earth Scan, 2001); Luke Eric Peterson, "Human Rights and Bilateral Investment Treaties: Mapping the Role of Human Rights Law within Investor State Arbitration”, (Rights \& Democracy (International Centre for Human Rights and Democratic Development), 2009); Organisation for Economic Cooperation and Development (OECD), International Investment Law: A Changing Landscape (OECD Publishing, 2005). 
agreement that allows for more flexibility, in the form of exceptions for public interest concerns, of a benevolent host state to regulate matters concerning social and environmental protection. ${ }^{3}$

The foremost issue of incorporating broader provision concerning social and environmental protection in an investment treaty concluded between states is the dilemma posing the requirement for a trade-off. Reducing the cost for internalizing the externalities on one hand, and increasing the chance for the host state's opportunistic behavior on the other. A standard economic argument for not providing compensation for a regulatory taking is acceptable when such action is designated to internalize the externalities that arise from market failure of the investment activities. ${ }^{4}$ However, introducing excessive discretion can create fiscal illusion when the purpose of the regulation is to deliver certain gain or benefit to the society. ${ }^{5}$ Further, one should also be aware of a potential regulatory capture, being a regulation that serves a certain private interest not at all related to any economic rationale. ${ }^{6}$

Besides, international investment legal regime has a peculiar feature that even adds up to more complexities: the non-existence of one single judicial body that serves as focal point to coordinate the development of jurisprudence over the matters. ${ }^{7}$ This feature is a logical consequence of the structure of international investment regime itself which consists of thousands of Bilateral Investment Treaties (BITs), bilateral and regional Free Trade Agreements (FTAs) that contained investment chapters, as well as investment-related provisions in the World Trade Organization (WTO) Agreement. Amid these complex settings, countries must negotiate among each others to incorporate efficient provisions into investment treaties.

This article will not deal with the question of optimal structure of regulatory discretion which is still debatable among scholars. Rather it assumes that the provision of several model BIT that provide greater flexibility including the United States Model of Bilateral Investment Treaty (US Model BIT) and the Canada Model of Bilateral Investment Treaty (Canada Model BIT) to be considerably sufficient to respond to the issue at hand. ${ }^{8}$

${ }^{3}$ OECD, supra note 1. See also Daniel Kalderimis, "Investment Treaties and Public Goods", (Presentation to AIELN Conference, Tokyo, 2009); Ursula Kriebaum, "Regulatory Takings: Balancing the Interests of the Investor and the State", 8 The Journal of World Investment and Trade (2007), p.717-744.

${ }^{4}$ For a general overview on takings and regulatory takings, see Thomas J. Miceli and Kathleen Segerson, "Takings", (1999) in Encyclopedia of Law and Economics, available at http://encyclo.findlaw. com/6200book.pdf

${ }^{5}$ See William A. Fischel, Regulatory Takings: Law, Economics, and Politics, (Harvard University Press, 1995); Richard A. Epstein, Takings: Private Property and the Power of Eminent Domain, (Harvard University Press, 1985).

${ }^{6}$ Epstein, supra note 5.

${ }^{7}$ Luke Eric Peterson, "The Global Governance of FDI: Madly Off in All Directions", (Friedrich Ebert Stiftung Dialogue on Globalization Occasional Paper No. 19, 2005). See also Efraim Chalamish, "The Future of Bilateral Investment Treaties: A De Facto Multilateral Agreement", 34 Brooklyn Journal of International Law 2 (2009). For the diffusion of BITs, see Zachary Elkins, Andrew T. Guzman, and Beth A. Simmons, "Competing for Capital: The Diffusion of Bilateral Investment Treaties, 1960-2000", International Organization 60 (Fall 2006): p. 811-846.

${ }^{8}$ There are also Model BIT offered by civil societies including that from the International Institute for Sustainable Development (IISD) (see http://www.iisd.org/investment/model/ (last access 1 August 2010). The United States (USS) has also asked reputable civil societies including Oxfam, Friends of the Earth, and Center for International Environmental Law (CIEL) to provide input for their Model BIT revision. See http://www.ciel.org/Tae/US_ModelTreaty_230ct09.html (last access 31 July 2010). These model will be neglected in the article analysis. 
The central agenda of this article is to address the precondition for that efficient outcome to materialize within the complex web of BITs already signed among states. It is even more complex to be concluded. This issue is due to the absence of international coordinating institution, letting alone that of global supranational authority. This is different from the case of domestic regulatory takings which requires "simply" the correct information and measure from the benevolent government, that said, the existence of an efficient provision, if any, will not necessarily result in an efficient outcome.

The building blocks of this article will be based on the following two underlying frameworks. Firstly, although allowing flexibility of a BIT would increase the joint surplus of both the capital exporting state and the host state, there is no credible threat from the potential host states to the capital exporting state that can compel the latter to modify its offer in a BIT negotiation. When an agreement is considered to be inefficient, the economics of contract reserves one party to commit an "efficient breach" to such agreement. ${ }^{9}$ However credible this efficient breach threat is, there is little evidence that this will affect the global market for international investment treaty negotiation. ${ }^{10}$ One possible explanation is that investment treaty serves not only as a country's commitment to foreign direct investment (FDI) per se, but also as commitment and reputation to the country's global economic position in general. This incurs highly inefficient reputational costs for an efficient breach to prevail. Potential host states have weaker bargaining power to influence the result of the negotiation (and renegotiation), thus the capital exporting states can de facto unilaterally determine the structure of an investment treaty.

Secondly, the structure of the global BITs network resembles that of a prisoner's dilemma model between potential host states that prevent collective action demanding flexible provisions in BIT negotiation. ${ }^{11}$ This situation assumes two possible alternative structures of an investment treaty. The one with strict provisions and the other with flexible provisions. Potential host states will always prefer the latter and at the same time recognize that the capital-exporting countries prefer the former. Collectively potential host states are better off by forming a collusion not to sign BIT. However, individually, each has the incentive to attract capital and sign BIT.

Having considered the above underlying frameworks, the article argues that although allowing for more discretion in regulating public interest is desirable from the efficiency point of view, the current structure of the global investment architecture prevents any significant modification driven by the potential host states, as the parties suffering from losses. High reputational costs and high transaction costs become the major stumbling block of any demand for efficient outcome.

Besides, suppose one would view this as a Coasian bargaining with positive transaction costs, the efficient outcome would prevail if the initial entitlement (being the right of having more regulatory discretion) is properly

\footnotetext{
${ }^{9}$ Charles Goetz and Robert Scott, "Liquidated Damages, Penalties, and the Just Compensation Principle: A Theory of Efficient Breach", 77 Columbia Law Review 554 (1977).

${ }^{10}$ See sub-section C.1 for further details.

${ }^{11}$ See sub-section C.1 for further details. The argument is developed from Guzman's model of competition among developing countries. See Andrew T. Guzman, "Why LDCs Sign Treaties That Hurt Them: Explaining the Popularity of Bilateral Investment Treaties", Virginia Journal of International Law 38 (1998): p. 639-688.
} 
assigned to the ones who value the most. ${ }^{12}$ However, in the world absence of global supranational authority this initial assignment is again not feasible and the result would solely depend on the negotiation and bargaining between the relevant parties. Therefore, in the market for BITs, the remaining option to drive the movement towards efficient outcome should come from the supply of the capital exporting states.

The question is then, why would a capital exporting state be driven to change the provision of a BIT which, although welfare-enhancing jointly, will increase the risk of higher chance of opportunistic behavior from the potential host states? This leads to the main question presented in the article: under what condition a capital exporting state could introduce higher flexibility for regulating public interest in an investment treaty negotiation? In order to address the question, a full and comprehensive framework concerning the relations among the capital exporting states, foreign investors, and potential host states should be taken into account, including the underlying economic rationale and political context.

One important insight is the different in nature between foreign direct investors, which only concern about profit maximization, and host states which also have distributional concerns for their domestic stakeholders. A comprehensive analysis of the relationship between them must take into account domestic interest groups that influence a state's preferences.

Another insight rests upon the basic political science model of Obsolescing Bargaining Mechanism (OBM). ${ }^{13}$ This theory argues that foreign investors have relatively more ex ante bargaining power prior to an investment being made because of their mobility, as opposed to the host states which depend on immobilized and given certain endowment factors. This early advantage would however shift in favor of host states' ex post benefit, because once the capital is injected, it would be locked-in inside that particular country's territory for a long period, and the host states can commit actions to level up its position. However, in practice foreign investors can still retain their bargaining power even after the investment has been made. ${ }^{14}$ One assumption that did not hold up in the standard theory is that investment negotiation is a one-shot game, and contractual agreements (including BITs) are the only way to influence the relationship structure between the investor and the host state. This standard theory thus assumes that investors have little impact on local institutions or policies, while the real fact is the contrary.

Therefore, with regard to the incorporation of flexible provisions on social and environmental issues in BITs, it is argued that foreign investors may not necessarily lose their bargaining advantage and can still retain their strong ex ante bargaining power if they can influence the domestic legal system of the host states to protect their interests. This however does not entail absolute assurance that foreign investors would succeed through this means, because they have to compete with the preferences of other interest groups in that political market. An economic assessment should address the trade-off between

\footnotetext{
${ }^{12}$ Ronald H. Coase, "The Problem of Social Cost", 3 Journal of Law and Economics 1 (1960).

${ }^{13}$ Raymond Vernon, Storm over the Multinationals: The Real Issues, (Harvard University Press, 1977).

${ }^{14}$ Witold J. Henisz and Bennet A. Zelner, "Legitimacy, Interest Group Pressures and Institutional Change: The Case of Foreign Investors and Host Country Governments", (William Davidson Institute Working Paper Number 589, 2003).
} 
protection under BITs and influences over domestic legal system. The analysis of this trade-off will ultimately answer the article's main question of explaining normative conditions that promote higher flexibility for regulating social and environmental issues in BITs.

The main research question addressed in the article is: under what condition a capital exporting state could introduce higher flexibility for regulating public interest in an investment treaty negotiation?

The article is mainly theoretical and blends insights, doctrines, and models from three disciplines of law, economics, and political science. It is developed to discuss, analyze, criticize, and deconstruct the prevailing theories related to the issues based on other theories, empirical findings, and country-specific case studies. An informal theoretical model is built in the final section to frame the main argument of the article.

This articel introduces the state of the art and framework of the article, discusses a short history of BITs and the development of social and environmental provisions in BITs. This also includes the emerging jurisprudence in investor-state arbitrations in the subject matter, analyses theoretical economic foundations of the issues, develops an informal model that attempts to explain a possible Pareto improving exchange between capital exporting states and potential host states in a BIT negotiation, and concludes the findings and summarizes the answers of the article question.

\section{Social and Environmental Protection in Bilateral Investment Treaties}

\section{BITs and Social and Environmental Provisions in a Nutshell}

Bilateral Investment Treaty, a treaty concluded between two states designed to regulate investment between them, serves as an international legal instrumenttoattract foreigninvestment byproviding security to foreign investors, mainly in developing countries where "fear of expropriation might otherwise deter investment." 15 The first BIT was entered into in 1959 between Germany and Pakistan, and since then the BITs network has increased drastically. There has been a massive proliferation of BITs over the past 20 years, with the present total number of BITs concluded exceeds 2600. ${ }^{16}$ Even during 2008, when there was a growing concern of economic nationalism, the general tendency was one of greater openness, with 58 new BITs were concluded. ${ }^{17}$ To date, most BITs have been concluded between a developed country and a developing country, despite the fact that as of 2008 most inward foreign investment still flows between developed countries, as the table demonstrates below. The later issues however show that legal disputes concerning social and environmental protection are not limited to those between a developed country and a developing country, but rather more on a general basis.

\footnotetext{
${ }^{15}$ Tom Ginsburg, "International Substitutes for Domestic Institutions: Bilateral Investment Treaties and Domestic Governance", International Review of Law and Economics 25 (2005).

16 The exact number according to the World Investment Report 2009 of UNCTAD is $2676 \mathrm{http}: / /$ unctad.org/en/docs/wir2009_en.pdf (last access 2 August 2010).

${ }^{17}$ Supra note 16.
} 
FDI Inward

(Measure is in million US Dollars)

\begin{tabular}{|c|c|c|c|c|c|c|c|c|c|}
\hline \multicolumn{2}{|c|}{ YEAR } & \multirow[t]{2}{*}{2001} & \multirow[t]{2}{*}{2002} & \multirow[t]{2}{*}{2003} & \multirow[t]{2}{*}{2004} & \multirow[t]{2}{*}{2005} & \multirow[t]{2}{*}{2006} & \multirow[t]{2}{*}{2007} & \multirow[t]{2}{*}{2008} \\
\hline ECONOMY & MODE & & & & & & & & \\
\hline $\begin{array}{l}\text { Developing } \\
\text { economies }\end{array}$ & $\begin{array}{l}\text { Flow } \\
\text { Stock }\end{array}$ & $\begin{array}{r}215,421.14 \\
1,795,446.8\end{array}$ & $\begin{array}{r}175,934.92 \\
1,757,930.5\end{array}$ & $\begin{array}{r}183,993.96 \\
2,008,177.8\end{array}$ & $\begin{array}{r}290,397.31 \\
2,338,132.1\end{array}$ & $\begin{array}{l}329,291.5 \\
2,722,292\end{array}$ & $\begin{array}{r}433,763.66 \\
3,363,925.4\end{array}$ & $\begin{array}{r}529,344.21 \\
4,393,354.3\end{array}$ & $\begin{array}{r}620,733.33 \\
4,275,982\end{array}$ \\
\hline $\begin{array}{l}\text { Transition } \\
\text { economies }\end{array}$ & $\begin{array}{l}\text { Flow } \\
\text { Stock }\end{array}$ & $\begin{array}{l}9,724.9883 \\
88,054.662\end{array}$ & $\begin{array}{l}11,292.724 \\
115,440.93\end{array}$ & $\begin{array}{l}19,900.638 \\
15,4398.65\end{array}$ & $\begin{array}{l}30,308.416 \\
198,930.77\end{array}$ & $\begin{array}{l}30,948.232 \\
273,428.67\end{array}$ & $\begin{array}{l}54,548.218 \\
395,251.51\end{array}$ & $\begin{array}{l}90,866.085 \\
676,060.67\end{array}$ & $\begin{array}{l}114,361.19 \\
420,413.93\end{array}$ \\
\hline $\begin{array}{l}\text { Developed } \\
\text { economies }\end{array}$ & $\begin{array}{l}\text { Flow } \\
\text { Stock }\end{array}$ & $\begin{array}{r}595,283.85 \\
4,246,309.8\end{array}$ & $\begin{array}{r}442,447.63 \\
4,866,401.1\end{array}$ & $\begin{array}{r}361,264.92 \\
5,997,833.2\end{array}$ & $\begin{array}{r}414,186.32 \\
7,070,737.8\end{array}$ & $\begin{array}{r}613,089.34 \\
7,055,164.2\end{array}$ & $\begin{array}{r}972,762.25 \\
8,645,261.7\end{array}$ & $\begin{array}{r}1,358,627.6 \\
10,591,083\end{array}$ & $\begin{array}{l}962,258.67 \\
10,212,893\end{array}$ \\
\hline
\end{tabular}

Source: World Investment Report 2009, statistics available at http://stats.unctad.org

There are several basic features in the provisions of a BIT, including the definition of investments, standard of treatments (fair and equitable treatment, national treatment, and most favored nations), repatriation of profits, and expropriation and compensation. ${ }^{18}$ The latter issues play an important role as far as public interest is concerned. BITs are considered to have reinvigorated the customary international law of "prompt, adequate, and effective" compensation over nationalization, also known as the "Hull Rule".19 However, following the movement of decolonialisation in the postWorld War-II era, the newly established states strongly opposed its status as customary international law and felt no legal obligation to comply with such. ${ }^{20}$ Having considered the afore context, the emergence of BITs which have again incorporated the compensation principle similar to that of the Hull Rule. The emergence of BIT's have as well placed strong protection toward foreign investors arguably swinging the international legal path back to its conservative tradition.

While the issue of compensation rule has perhaps been settled with BITs as de facto multilateral agreement on investment, ${ }^{21}$ the present focus as to the matter has now shifted to the expanding character of expropriation that also covers indirect expropriation, mostly in the form of government regulations or policies. BITs contain brief and general indirect expropriation provisions which focus on the effect of the government action and do not address the distinction between compensable and non-compensable regulatory actions. ${ }^{22}$

These intricate one to qualify the general international law definition of indirect expropriation and requires one to decide any issue on a case-bycase basis. Those depend on the specific wording of the relevant treaty, such as "measures of expropriation or nationalisation or any other measures the effect of which would be direct or indirect dispossession" or "any direct or indirect measure" or "any other measure having the same nature or the same 2004).

${ }^{18}$ M. Sornarajah, The International Law on Foreign Investment, (Cambridge University Press,

${ }^{19}$ See Sornarajah, supra note 18, Guzman, supra note 11, and Andrew Newcombe and Lluis Paradell, Law and Practice of Investment Treaties: Standard of Treatment, (Kluwer Law International, 2009).

${ }^{20}$ The strongest opposition came from the Government of Mexico. Three United Nations (UN) General Assembly (GA) Resolutions that stress out the opposition are the Resolution 1803 on Permanent Sovereignty Over Natural Resources G.A. res. 1803 (XVII), 17 U.N. GAOR Supp. (No.17) at 15, U.N. Doc. A/5217 (1962); Resolution 3171 on Permanent Sovereignty Over Natural Resources G.A. res. 3171 (XXVIII), 28 U.N. GAOR Supp. (No.30) at 52, U.N. Doc. A/9030 (1974); and Resolution 3201 on New International Economic Order G.A. res. 3201 (VI), 6 U.N. GAOR Supp. (No.1) at 3, U.N. Doc. A/9559 (1974).

${ }^{21}$ Chalamish, supra note 7.

${ }^{22}$ See OECD, supra note 1. 
effect against investments" or "having effect equivalent to nationalisation or expropriation" or "any other measure or series of measures, direct or indirect, tantamount to expropriation (including the levying of taxation, the compulsory sale of all or part of an investment, or the impairment or deprivation of its management, control of economic value..." ${ }^{23}$ Further, growing number of cases and jurisprudences concerning indirect expropriation (and in particular environmental regulations) are centered on the North American Free Trade Agreement (NAFTA) Chapter 11 on Investment. It is of particular relevance to discuss and compare the development of the issues in the NAFTA context, which in Article 1110 of the Agreement stipulates that:

"No Party may directly or indirectly nationalise or expropriate an investment of an investor of another Party in its territory or take a measure tantamount to nationalisation or expropriation of such an investment, except:

(a) for a public purpose;

(b) on a non-discriminatory basis;

(c) in accordance with due process of law and Article 1105 (1)15 and

(d) on payment of compensation in accordance with [subsequentparagraphs specifying valuation of expropriations and form and procedure of payment]"

As a response to the growing concern about the importance of regulatory discretion, especially with regard to the state's right to pursue social and environmental objectives, and in addition to the growing number of jurisprudence in investor-state dispute in this matter, there have been trends to incorporate provisions that cover broader scope of protection. The US Free Trade Agreements (FTAs) concluded with Australia, ${ }^{24}$ Chile, ${ }^{25}$ Central America, ${ }^{26}$ and Morocco, ${ }^{27}$ refer to the US Model BIT 2004, ${ }^{28}$ incorporated the following provisions:

"The determination of whether an action or series of actions by a Party, in a specific fact situation, constitutes an indirect expropriation, requires a caseby-case, fact-based inquiry that considers, among other factors;

(i) the economic impact of the government action, although the fact that an action or series of actions by a Party has an adverse effect on the economic value of an investment, standing alone, does not establish that an indirect expropriation has occurred;

(ii) the extent to which the government action interferes with distinct, reasonable, investment-backed expectations; and

(iii) the character of the government action."

\footnotetext{
${ }^{23}$ Rudolf Dolzer and Margrete Stevens, Bilateral Investment Treaties, (Brill, 1995), p. 99-100.

${ }^{24}$ US-Australia Free Trade Agreement, signed on 1 March 2004 (see Annex 11-B).

${ }^{25}$ The US-Chile Free Trade Agreement, signed on 6 June 2003 (see Annex 10-D).

${ }^{26}$ US-Central America Free Trade Agreement (CAFTA), signed on 28 January 2004 (see Annex 10 C). The Central American countries are: Costa Rica, El Salvador, Guatemala, Honduras, and Nicaragua.

${ }^{27}$ US-Morocco Free Trade Agreement, signed on 15 June 2004 (see Annex 10-B).

${ }^{28}$ For the text of the model BIT see http://www.state.gov/documents/organization/117601.pdf (last access 2 August 2010).
} 
In addition, the agreements also address the right to regulate as follows: "Except in rare circumstances, non-discriminatory regulatory actions by a Party that are designed and applied to protect legitimate public welfare objectives, such as public health, safety and the environment, do not constitute indirect expropriations."

The updated 2004 version of Canada's model Foreign Investment Promotion and Protection Agreement (FIPA) apparently contains the exact similar wordings as that of the above US 2004 Model BIT, as far as indirect expropriation and regulatory discretion are concerned. ${ }^{29}$

One revolutionary BIT proposal was offered by Norway, which draft was issued to the public in 2007 until finally revoked in 2009 due to failure to gain enough public support. ${ }^{30}$ The draft moved beyond the standard investor protection to include other goals of corporate social responsibility, human rights commitments, anti-corruption efforts, sustainable development, and "the basic principles of transparency, accountability and legitimacy for all participants in foreign investment processes" ${ }^{31}$ Regulations could have been enacted to set aside investor protection under broad basis of exceptions, including public morals and public orders; human, animal, or plant life or health; national treasures of artistic, history, or archaeological value; protection of environment; financial system prudence; international peace and security; and linguistic heritage and cultural diversity. ${ }^{32}$

\section{a. Relevant Cases}

The changing trends toward broader exceptions in BIT are mainly driven by the enormous high profile investor-state disputes concerning public interest regulations and at present many foreign investors still resort this forum to channel their interests.

One of particular relevance to environmental protection issue is that between a Spanish firm Técnicas Medioambientales Tecmed, S.A. (Tecmed), against the Government of Mexico adjudicated under the ICSID forum pursuant to the Spain-Mexico BIT. The issues were related to Tecmed's investment in a waste landfill to operate a hazardous waste confinement facility in Hermosillo, which Tecmed alleged to have lost in 1998 due to non renewal of the necessary licenses by the Mexican government. The Tribunal eventually found that Mexico's actions indeed constituted expropriation and also violated its 'fair and equitable treatment' obligation. ${ }^{33}$

\footnotetext{
${ }^{29}$ For the text of the new FIPA model and the list of countries with which Canada has entered into contract, see http://www.international.gc.ca/trade-agreements-accords-commerciaux/agr-acc/fipa-apie/ index.aspx (last access 25 July 2010).

${ }^{30}$ Damon Vis-Dunbar, "Norway shelves its draft model bilateral investment treaty", 8 June 2009, http://www.investmenttreatynews.org/cms/news/archive/2009/06/08/norway-shelves-its-proposedmodel-bilateral-investment-treaty.aspx (last access 25 July 2010).

${ }^{31}$ Investment Treaty News (ITN), March 27, 2008, www.iisd.org/pdf/2008/itn_mar27_2008.pdf (last access 25 July 2010).

${ }^{32}$ For the complete provisions, see the Norwegian Model Agreement for the Protection and Promotion of Investments (Section 5- Exceptions) http://ita.law.uvic.ca/documents/NorwayModel2007. doc (last access 25 July 2010).

33 Técnicas Medioambientales Tecmed, S.A. v. United Mexican States (ICSID Award Case No. $\mathrm{ARB}(\mathrm{AF}) / 00 / 2)$
} 
In Compania del Desarrollo de Santa Elena SA (CDSE) vs. Republic of Costa Rica, similar environmental measures on the extension of Santa Rosa National Park to preserve rare species were adjudicated, but not so much in terms of determining the legality of the act, (the fact of expropriation as such was not in dispute), but rather in the methodology for valuing the environmental resource - in this case an area of rain forest which is rich in biological diversity. ${ }^{34}$

Until recently the similar type of disputes still gain public attention. In Unglaube vs. Government of Costa Rica, ${ }^{35}$ a German investor registered a request for arbitration on November 2009 in ICSID under the German-Costa Rica BIT. The Government of Costa Rica has refused to extend the appropriate permits for the eco-tourism hotel projects, although it was already declared as "nature friendly" in 1992, citing its danger to the extinction of the leatherback turtle species. Further, Phillip Morris International (PMI) is currently facing the Government of Uruguay in measures concerning public health. ${ }^{36} \mathrm{PMI}$, having its headquarter in Switzerland, in May 2010 initiated an ICSID arbitration against Uruguay under the Switzerland-Uruguay BIT over new rules requiring that $80 \%$ of cigarette pack surfaces be devoted to graphic warnings of the dangers associated with smoking, and limits tobacco companies to marketing only one type of cigarette per brand, which law prevents them from marketing "light" or "mild" cigarettes.

However, most landmark cases have been decided under the NAFTA tribunals, which make them relevant to be discussed herein.

In October 1996, Metalclad Corporation, a US waste-disposal company, accused the Mexican government of violating Chapter 11 of NAFTA when the local government of San Luis Potosi refused their local subsidiary a license to re-open a waste disposal facility. The State Governor ordered the site closedown after a geological audit found the facility would contaminate the local water supply. Special NAFTA tribunal, operating under the rules of the World Bank's International Center for the Settlement of Investment Disputes (ICSID) Additional Facility Rules, awarded Metalclad \$16,685,000 in August 2000, and finally in June 2001 the parties reached a settlement of US\$15.6 million. ${ }^{37}$

In 1997 the US chemicals giant, Ethyl Corp, used NAFTA Chapter 11 to sue the Canadian government for a ban imposed on Methylcyclopentadienyl Manganese Tricarbonyl (MMT), a gasoline additive designed to prevent automobile engine from knocking produced by Ethyl, because it was toxic and hazardous to public health. Ethyl sued the Canadian government for US $\$ 250$ million. In June 1998, the Canadian government withdrew environmental legislation banning MMT, and paid Ethyl Corp US\$13 million to settle the case. ${ }^{38}$

\footnotetext{
${ }^{34}$ Compañía del Desarrollo de Santa Elena S.A. v. Republic of Costa Rica, (ICSID Case No. ARB/96/1; 17 February 2000).

${ }^{35}$ Fernando Cabrera Diaz, "German investor launches ICSID case against Costa Rica over alleged expropriation of land near endangered turtle habitat", http://www.investmenttreatynews.org/cms/ news/archive/2009/12/04/german-investor-launches-icsid-case-against-costa-rica-over-allegedexpropriation-of-land-near-endangered-turtle-habitat.aspx (last access 1 August 2010).

${ }^{36}$ Fernando Cabrera Diaz, "Philip Morris initiates arbitration against Uruguay over new labeling requirements, taxes" http://www.investmenttreatynews.org/cms/news/archive/2010/05/11/philipmorris-initiates-arbitration-against-uruguay-over-new-labeling-requirements-taxes.aspx (last access 1 August 2010).

${ }^{37}$ Metalclad Corporation v. United Mexican States (NAFTA Tribunal Decision 30 August 2000).

${ }^{38}$ Ethyl Corporation v. Canada (NAFTA Tribunal Preliminary Award on Jurisdiction, 24 June 1998).
} 
Moreover, S.D. Myers, Inc. (SDMI), a US company engaged in treatment of Polychlorinated biphenyl (PCB) alleged Canada for violating NAFTA Chapter 11 by banning the export of PCB waste to the US. In 1980 the U.S. closed the border for the movement of PCB waste, but in the fall of 1995 SDMI was granted permission to import PCB from Canada. Promptly after this, Canada issued a regulation prohibiting the export of PCB waste to the U.S. thus disqualifying SDMI, and its Canadian investment, from carrying out its intended business. ${ }^{39}$

One case in which the decision went against the foreign investor was one of Methanex vs. USA, rendered in 2005. In its suit, Methanex claimed that the MTBE ban was disguised protectionism pushed by its competitor through campaign contributions. However, the tribunal found that the ban was enacted for a legitimate public purpose, pursuant to extensive public debate, sound scientific opinion and in accordance with due legislative process. ${ }^{40}$

These disputes have contributed to the development of investment jurisprudence to dissect and determine what constitutes legitimate public interest regulations that justify indirect expropriations.

First is the degree of interference of property, which means how severe the economic impact is. In S.D. Myers, the Tribunal distinguished regulation from expropriation primarily on the basis of the degree of interference with property rights: "expropriations tend to involve the deprivation of ownership rights; regulations [are] a lesser interference". ${ }^{41}$ Duration of regulation also plays a role in S.D. Myers, as the Tribunal concluded that Canada's initiative "was only valid for a time" and thus "an opportunity was delayed" but no indirect expropriation could be found. ${ }^{42}$

More controversial issue arises as to whether the consideration should only take the economic impact (known as the "sole effect doctrine") into account or the political motive (public choice analysis) of the regulation as well. In Metalclad, the Tribunal stated that it "need not decide or consider the motivation, nor intent of the adoption of the Ecological Decree". ${ }^{43}$ In CDSE, the panel expressly stated that the environmental purpose had no bearing on the issue of compensation. ${ }^{44}$

These considerations are related to the purpose and the context of the regulation, as to whether the recognition of the "social purpose" or "general welfare" makes a difference in determining whether takings have taken

${ }^{39}$ S.D. Myers, Inc. v. Canada, (NAFTA Tribunal, Partial Award, 13 November 2000).

${ }^{40}$ Methanex v. United States (NAFTA Tribunal Final Decision, 3 August 2005).

${ }^{41}$ S.D. Myers, supra note 39. The Tribunal states: "the distinction between expropriation and regulation screens out most potential cases of complaints concerning economic intervention by a state and reduces the risk that governments will be subject to claims as they go about their business of managing public affairs".

${ }^{42}$ S.D. Myers, supra note 39.

${ }^{43}$ Metalclad, supra note 37.

${ }^{44}$ CDSE, supra note 34 . The arbitration panel declares that "while an expropriation or taking for environmental reasons may be classified as a taking for a public purpose, and thus be legitimate, the fact that the property was taken for this reason does not affect either the nature or the measure of the compensation to be paid for the taking. That is, the purpose of protecting the environment for which the Property was taken does not alter the legal character of the taking for which adequate compensation must be paid. The international source of the obligation to protect the environment makes no difference".

Further it is added: "Expropriatory environmental measures - no matter how laudable and beneficial to society as a whole - are, in this respect, similar to any other expropriatory measures that a state may take in order to implement its policies: where property is expropriated, even for environmental purposes, whether domestic or international, the state's obligation to pay compensation remains". 
place. In S.D. Myers, "require a tribunal to look at the substance of what has occurred and not only at form. A tribunal should not be deterred by technical or facial considerations from reaching a conclusion... It must look at the real interests involved and the purpose and effect of the government measure". ${ }^{45}$ In Tecmed, ${ }^{46}$ in addition to economic analysis and proportionality test (there must be a reasonable relationship of proportionality between the charge or weight imposed upon the foreign investor and the aim sought to be realized by any expropriatory measure), it confirmed the irrelevance of the regulatory motives. ${ }^{47}$ At the same time, Tecmed recognized the importance of commonlyaccepted police-power doctrine, although decided that the Mexican regulation in question did not fall into the category. ${ }^{48}$

Final element identified is whether the governmental measure affects the investor's reasonable expectations. In these cases the investor has to prove that his/her investment was based on a state of affairs that did not include the challenged regulatory regime. The claim must be objectively reasonable and not based entirely upon the investor's subjective expectations. In Tecmed, the Tribunal determined whether the Mexican government's measures were "reasonable with respect to their goals, the deprivation of economic rights and the legitimate expectations of who suffered such deprivation". ${ }^{4}$

\section{The Benefit Revisited : Economic Framework of Bilateral Investment Treaties}

As explained above, this paper does not seek the optimal level of a benevolence regulation that falls outside the scope of regulatory expropriation or develop a new formula to determine one. Rather, it presents the question on under what condition the optimal level may emerge in the complex global network of BITs. This is to assume that relaxing the exception requirements in BITs that provide more rooms for government regulations is more efficient and incur joint surplus for both parties. The analysis will focus on the incentive structures of the BIT signatories, as well as the cost and benefit associated with signing one.

\section{Theoretical Economic Framework of BITs}

\section{a. Obsolesce Bargaining or Obsolesce Theory?}

BITs arise out of the classical commitment problem between a foreign trader (or a foreign investor for this matter) and a ruler. However, while the

\footnotetext{
${ }^{45}$ S.D. Myers, supra note 39.
}

${ }^{46}$ Tecmed, supra note 33.

47 Tecmed, supra note 33, points out that "under international law, the owner is also deprived of property where the use or enjoyment of benefits related thereto is exacted or interfered with to a similar extent, even where legal ownership over the assets in question is not affected, and so long as the deprivation is not temporary. The government's intention is less important than the effects of the measure [i.e. the economic value of the use, enjoyment or disposition of the assets or rights affected by the administrative action or decision have been neutralized or destroyed] on the owner of the assets or on the benefits arising from such assets affected by the measures; and the form of the deprivation measure is less important than its actual effects."

${ }^{48}$ Tecmed, supra note 33 further stipulates that "the principle that the State's exercise of its sovereign power within the framework of its police power may cause economic damage to those subject to its powers as administrator without entitling them to any compensation whatsoever is undisputable".

${ }^{49}$ Tecmed, supra note 33. 
traditional institutional solutions place heavy role on the reputation of the ruler, as for the case of the Medieval Merchant Guilds, ${ }^{50}$ BITs offer unique enforcement mechanisms that constitute the ruler's "credible commitment" for foreign investors by ensuring that the ruler would not break pre-investment promises once the investment has been made. ${ }^{51}$ BITs, adequately safeguard the investor against host states' actions that would adversely impact the profitability of the investment, since it is equipped with direct investor-state dispute resolution mechanisms and compensation for expropriation.

Formally the underlying model is known as the Obsolescing Bargaining Mechanism (OBM). ${ }^{52}$ This theory views that foreign investors have relatively more ex ante bargaining power prior to an investment being made because of their mobility that they can invest wherever the resources exist, as opposed to the host states which depend on immobilized and given certain endowment factors, say natural resources or intensive labors. Foreign investors in general, yet this depend on the nature of investment, can offer the host state capital, management know-how, marketing skills, advanced technology and access to export markets. ${ }^{53}$ The host state's bargaining chip include its market size and growth prospects, access to cheap and/or highly skilled labor, natural resources, infrastructure, and an investor-friendly regulatory regime. ${ }^{54}$

This early advantage would however shift in favor of host states' ex post benefit, because once the capital is injected, it would be locked-in inside that particular country's territory, as if a "hostage" 55 , for a long period, because FDI is mostly on a long-term basis. As such the host states can commit any action to lever up its position to gain more advantage, from raising the tax level to expropriating the investor's property. ${ }^{56}$ The investors' advantages thus obsolesce over time. Even with due observance of the host states' needs for capital investment, they would have an incentive to make those promises necessary to bring investors in, but once the sunk costs are made, the host then deliver the incentive only to the level that will keep the investor from leaving.

Besides, there is also a paradox that the greater the foreign investors' assets used as bargaining chip ex ante, the greater liability they would possess in the ex-post investment phase. While foreign investors might succeed in getting a favorable initial deal, the agreement might not last for long if immobile fixed assets are involved. In countries where the risk of expropriation (including indirect expropriation) is high, the host government's inclination to violate contracts increases in line with the degree of asset specificity; ${ }^{57}$ which makes

\footnotetext{
${ }^{50}$ See Avner Greif, Institutions and the Path to the Modern Economy: Lessons from Medieval Trade (Political Economy of Institutions and Decisions), (Cambridge University Press, 2006).

${ }^{51}$ Guzman, supra note 11.

${ }^{52}$ Vernon, supra note 13.

53 See Jo Jakobsen, "Does Democracy Moderate the Obsolescing Bargaining Mechanism? An Empirical Analysis 1983-2001", available at http://www.unctad.org/en/docs/iteiit20063a3_en.pdf (last access 20 July 2010). See also Nathan Fagre and Louis T. Wells, "Bargaining Power of Transnationals and Host Governments", 13 Journal of International Business Studies, 13(1982), p. 9-23; Sushil Vachani, "Enhancing the Obsolescing Bargain Theory: A Longitudinal Study of Foreign Ownership of U.S. and European Transnationals", 26 Journal of International Business Studies 1 (1995), p. 159-180.

${ }^{54}$ Jakobsen, supra note 53; and John H. Dunning, "Location and the Multinational Enterprise: A Neglected Factor?", 29 Journal of International Business Studies 1 (1998), p. 45-66.

${ }^{55}$ See the analogy of the "Ugly Princess" to overcome the problem of credible commitment during the Middle Ages in Oliver E. Williamson, The Economic Institutions of Capitalism, (Free Press, 1998).

${ }^{56}$ Fagre and Wells, supra note 54; Vachani, supra note 54.

${ }^{57}$ Williamson, supra note 55.
} 
investments, involving large sunk costs or specific investments, a particularly risky activity. ${ }^{58}$ BITs supposedly serve to overcome this problem by providing an institutional safeguard that prevents such opportunistic behavior of the host states.

Despite its logical modeling, the theory fails to take into account more complex reality in foreign investment dynamics.

Firstly, the model assumes that the final objectives of foreign investors and potential host states are always contradictory, as not always is the case in the real world. The many test studies suggest that foreign investors were able to retain relative bargaining power and prevent opportunistic behavior conducted by host states. In fact, the competition among potential host states to attract foreign investors has shifted their policy and treatment of foreign investors from "red tape" to "red carpet" and from expropriation to liberalization. ${ }^{59}$

Secondly, the theory views investor-state relations as a single one-shot relationship and thus discounts the risk-reducing role of reputational concerns. ${ }^{60}$ In fact, when deciding where to invest foreign investors typically pay particular attention to the experiences of past and existing investors. ${ }^{61}$ "Unfavorable host state behavior is likely to have strong ripple effects beyond the investment immediately affected, as other existing investors withdraw from the host state, and as potential investors redraw their investment plans." 62

Thirdly, the model assumes that all relevant parties have similar characteristics in nature. As a single entity, foreign investor is interested solely in maximizing investment returns. Meanwhile, government as the entity that serves and aggregates interests of their stakeholders have more complex preferences, as reflected by various pressure groups. ${ }^{63}$ The relationship between host states and foreign investors is therefore a dynamic one in which preferences and reactions of many parties should be taken into consideration, and the outcome of an investment must be distributed among them. It means that it is again assumed that all relevant parties can influence each others during the negotiation of the contract, but once it is concluded, no more influence should be made but to respond to the final agreement (either adherence or non-compliance). The later sections will discuss about foreign investors' ability to infiltrate into the host states' domestic political environment and become one of the domestic interest groups.

${ }^{58}$ David J. Teece, "Transaction Cost Economics and the Transnational Enterprise", 7 Journal of Economic Behavior and Organization 7 (1986), p. 21-45.

${ }^{59}$ Lorraine Eden and Stefanie Lenway, "From Obsolescing Bargain to the Political Bargaining Model" in Robert Grosse (ed.), International Business and Government Relations in the $21^{\text {st }}$ Century, (Cambridge University Press, 2005). See also John H. Dunning, "Governments and Multinational Enterprises: From Confrontation to Cooperation?", In Lorraine Eden and Evan Potter (eds.), Multinationals in the Global Political Economy, (Macmillan, 1993); Yadong Luo, "Toward a Cooperative View of MNC-host Government Relations: Building Blocks and Performance Implications", Journal of International Business Studies 32 (2001), p. 401-19; John M. Stopford, "The Growing Interdependence between Transnational Corporations and Governments", Transnational Corporations 3 (1994), p. 53-76.

${ }^{60}$ The role of Reputation plays a pivotal role in any law-and-economics analysis of international law. See Andrew T. Guzman, How International Law Works, (Oxford University Press: 2007).

${ }^{61}$ Jason Webb Yackee, "Do BITs Really Work? Revisiting the Empirical Link Between Investment Treaties and FDI", in Karl P. Sauvant and Lisa Sachs, The Effect of Treaties on FDI: Bilateral Investment Treaties, Double Taxation Treaties, and Investment Flows, (Oxford University Press, 2009).

${ }^{62}$ Yackee, supra note 61.

${ }^{63}$ Henisz and Zelner, supra note 14. 
Moreover, the model also employs skeptical views toward the quality of the domestic institutions and the enforceability of the law in host states, or at least, as having a "home court bias". BITs consequently guarantee certain standards of treatment that can be enforced via binding investor-state arbitration detached from any domestic judicial system and substitute weak legal institutions and assist countries with high levels of political risk to attract FDI. It is then assumed that countries with weak domestic property rights protection can increase their competitiveness by committing themselves to respecting the property rights of foreign investors. The riskier a country is, the more a BIT should work to attract FDI. The logic follows that riskier countries tend to absorb more FDI inflows when their commitments to protect investors are credible.

However, although the views about BITs capability to help at attracting investment by serving as a commitment device and signal, - that protecting property rights of the foreign investors are indisputable -, the credibility of this signal will also be influenced by the quality of the domestic institutions, be it of the legal system or of political stability affairs. This will be described later in the subsequent section about the benefit of investment treaties from various empirical studies.

\section{b. Flexible Provisions and Credible Threat}

The insights of contract economics into traditional legal analysis merge the conventional ex-post analysis (say, rights and obligations of parties upon violation of an agreement) and ex-ante decision analysis, discussing why and under what circumstances parties enter into a contract in the first place. The starting point for analysis is the notion of "complete contract", when the parties -assumed to have full rationality and perfect information- could draw up contract without any contracting imperfections including bounded rationality and unforeseeability, no transaction costs, and concluded in a perfect market setting.

However, this type of contract is impossible to draft and very costly to even try to come close at drafting one. Therefore, contracts will always be incomplete that they will fail to discriminate the ex-post states of the world that optimally call for different obligations. ${ }^{64}$ BITs are concluded to address problems that arise out of the long-term characteristics of investment projects. BITs are therefore far more fragile to uncertainty and exogenous shocks associated with investment environment than standard business contract, in the sense of uncertainty about the future (unforeseeability), uncertainty about the actions of the others players (asymmetrical information) and uncertainty about the meaning and scope of the contractual provisions (legal indeterminateness). ${ }^{65}$

In order to be optimal, a contract must assess the mutual benefit of the parties involved, being welfare enhancing in sum. That is to say that the participation constraint must be met prior to concluding the contract. While the ex-ante approach finds that contract must be rigid and definite to provide security and prevent opportunistic behavior, the ex-post approach under the

${ }^{64}$ Jean Tirole, “Incomplete Contracts: Where Do We Stand?”, 67 Econometrica 741 (1994) defines an incomplete contract as one that "does not exhaust the contracting possibilities envisioned in the complete contract". For specific application in international law, see Robert E. Scott and Paul B. Stephan, The Limits of Leviathan: Contract Theory and the Enforcement of International Law, (Cambridge University Press, 2006).

${ }^{65}$ Anne Van Aaken, "International Investment Law between Commitment and Flexibility: A Contract Theory Analysis”, 12 Journal of International Economic Law 507 (2009). 
shadow of uncertainty must allow a room for modification and flexibility. "Rigidity always hurts states since certain risks are shifted to them, whereas flexibility usually hurts the investor since the risk allocation is on his side." ${ }^{\prime 6}$ As such, a welfare-enhancing BIT must decide a tradeoff between ex-ante security and ex-post flexibility, as summarized below:

"A balance needs to be found between commitment and flexibility with the following goals of the contract in mind: securing a high level of cooperation ex ante, distinction between (desired) flexibility in relation to new circumstances on the one hand and cases of purely opportunistic breach of the contract ex post on the other and adequate compensation for the victim." 67

In a complete contract, parties would maximize their ex-ante commitment, because there is no assurance problem. The standard OBM model apparently only considers one side of the analysis by ensuring the ex-ante incentive structure for the host states to prevent their opportunistic behavior. However, the expost optimality is not perfectly addressed in the model, no matter whether the contract is still value maximizing or not, after the entire future uncertainties have been resolved as of the time of performance.

Without having careful evaluation of the ex-post side, all future risks and uncertainties will be borne solely by the host states. The next issue would be whether this situation is efficient, in the sense that host state is the superior risk-bearer, and foreign investors will be exempted from any risk responsibility. While this question requires further in-depth analysis, which then require to incorporate other international and private institutions handling investment risks such as Multilateral Investment Guarantee Agency (MIGA) or governmental guaranty companies such as the Overseas Private Investment Corporation (OPIC) ${ }^{68}$. Assigning the risks only to the host states does generate several economic issues.

BITs could turn into over-insurance scheme for foreign investors that might in turn suffer from the problem of moral hazard.$^{69}$ If a foreign investor recognizes that its project will always be compensated from any regulation, it might excessively invest because its private actions that diminish the value of social or environmental conditions would always be externalized to the host state. Foreign investors can also have "accounting illusion" that will affect their financial analysis over the costs and benefits associated with certain projects. Some projects will always be considered to be profitable because they do not take the social costs into the assessment.

${ }^{66}$ Van Aaken, supra note 65 . The move towards the balance of interest between host states and foreign investors has been discussed intensively among scholars. See Andrea K. Bjorklund, "The Necessity of Sustainable Development?", in Marie-Claire Cordonnier Seger, Markus Gehring and Andrew Newcombe (eds.), Sustainable Development in World Investment Law, (Kluwer Law International, forthcoming 2009/2010); Andrea K. Bjorklund, "Emergency Exceptions: State of Necessity and Force Majeure" in Peter Muchlinski, Federico Ortino and Christoph Schreuer (eds), The Oxford Handbook of International Investment Law, (Oxford University Press, 2008).

${ }^{67}$ Van Aaken, supra note 65.

${ }^{68}$ See Witold J. Henisz, "Institutional Environment for Multinational Investment", 16 Journal of Law, Economics, and Organization 2 (2000), p. 334-364; Lauge Skovgaard Poulsen, "Political Risk Insurance and Bilateral Investment Treaties: A View From Below", Columbia FDI Perspectives, No. 27, August 2, 2010.

${ }^{69}$ Louis Kaplow, "An Economic Analysis of Legal Transitions", 99 Harvard Law Review 511 (1986). 
While the abovementioned application of contract economics to investment treaties generates valuable input, the proponent concludes that having overly strict rigidity, without allowing for adequate flexibility, may lead to reactions by states that may threaten the system as a whole. Thereby, it leads to the ultimately perverse result of less protection for FDI in the long run. This is to assume that if states feel that they have no voice they might exit the system. ${ }^{70}$

The problem with this conclusion is that it is based on the assumption that host states can invoke credible threat to quit the system or violate the BIT. A threat is credible when it is rational and within one's best interest to do so. When circumstances surrounding BIT change, the host state might consider breaching as more attractive than performing. A credible threat serves as a basis for efficient breach, namely when the party (in this case the host state) will breach a contract and pay damages, if the party considered it would be more economically efficient than performing under the BIT. ${ }^{71}$ Besides, when the threat is credible, the host state may induce the counterpart to modify the original agreement. If the new circumstances are such that performance under the original terms would come to involve a loss for one party, his demand for better terms is viewed more favorably, and the resulting modification is more likely to be enforced. ${ }^{72}$ International law doctrines which can be invoked in this context is necessity pursuant to a change in circumstances or "rebus sic stantibus."73

There are two foundations -in international law in general and the network of BITs in particular- that make credible threat not credible, As such, the threat to exit the system as proposed does not hold up.

One element of international law left out in the previous analysis is the importance of reputation, upon which the entire international legal system is built. Reputation works in a very simple way: if a state breaches its international legal obligation, its future commitment to compliance with international circles will lack credibility. ${ }^{74}$ Should one ignore the importance of reputation in international sphere, the analysis will fail to comprehend many international legal phenomena. Reputation works however only if there is a common and shared perception and evaluation over an action..$^{75}$ When a state violates BIT under the consideration that the BIT does not incur joint maximizing benefit to its side, the reputation generated in the international community does not necessarily take on its side. It can gain support from other states, but it can also hamper the state's future international exchange although its action is based on solid economic reasoning.

In addition, particularly in the context of BITs, it has been discussed that BITs do not serve only as a device that provides security for foreign investors per $s e$, but also as commitment device that signals a state's overall preferences in the global economic exchange. ${ }^{76}$ The role of private international firms such as

${ }^{70}$ Van Aaken, supra note 65.

${ }^{71}$ Oren Bar-Gil and Omri Ben-Shahar, "Threatening an Irrational Breach of Contract”, Michigan Law and Economics Research Paper No. 02-016 (2002).

${ }^{72}$ Bar-Gil and Ben-Shahar, supra note 71.

${ }^{73}$ Vienna Convention on the Law of Treaties, adopted 22 May 1969, entered into force 27 January 1980, UN Doc. A/Conf.39/27; 1155 UNTS 331; 8 ILM 679 (1969); 63 AJIL 875 (1969).

${ }^{74}$ Guzman, supra note 60.

${ }^{75}$ Greif, supra note 50.

${ }^{76}$ See Jenifer Tobin and Susan Rose-Ackerman, "When BITs Have Some Bite: the Political Economic Environment for Bilateral Investment Treaties" (2006), as the result is summarized in Tobin and RoseAckerman, "Do BITs Benefit Developing Countries?" in Roger P. Alford and Catherine Rogers (eds.), The Future of Investment Arbitration, (Oxford University Press, 2009); Ginsburg, supra note 15; Kenneth 
political risk assessment consultancies, credit ratings agencies, and international development agents can help shaping perceptions as to one circumstance. ${ }^{77}$ In other words, investment treaty signals a country's commitment and reputation in the global market in general. The perception of which will affect also its participation in the global trade flows, international financial market, and even signals a country's political stability. This incurs highly inefficient reputational costs for an efficient breach to prevail. Potential host states have relatively weaker bargaining power to influence the result of the negotiation (and renegotiation), thus the capital exporting states can de facto unilaterally determine the structure of an investment treaty.

For example, so far Bolivia has announced its withdrawal from ICSID Convention and incorporated in its Constitution a prohibition of resource to foreign tribunals or jurisdictions in certain investment sectors, ${ }^{78}$ while Ecuador followed in the termination of BITs with eight Latin and Central American countries as well as withdrawal for matters related to natural resources adjudicated before ICSID effective as of January 2010, ${ }^{79}$ and Venezuela withdrew from the Venezuela-Netherlands BIT. ${ }^{80}$ Their actions were influenced by domestic political and ideological preferences and arguably did not impact the global investment network as a whole. ${ }^{81}$ In conclusion, the pretext of credible threat is not as credible as one would expect in the context of the global network of BITs.

\section{c. Observation and Verification of Social and Environmental Objectives}

It has been discussed above that long-term investments are always fragile to the uncertainty in the future. As far as social and environmental problems are concerned, the uncertainty is associated not only to the predictability and observability of an event that produces social and environmental problems, but also to the verifiability of such an event.

Most of the changes of circumstances related to social and environmental problems are not the results of exogenous shocks, but due to new discovery on the observability of certain issues. Say, emissions derived from oil and gas industry or coal mining have always been considered as sources of pollution, but when the threat of global warming started to emerge, the valuation of the costs of such pollution increased because they pose environmental dangers more than one have expected before. Another example is the existence of leatherback turtle, which plays a central role in ICSID dispute of Unglaube vs. Government of Costa Rica under the German-Costa Rica BIT. The species is the largest of all living sea

Vandevelde, "The Economics of Bilateral Investment Treaties", 41 Harvard International Law Journal 470, 490 (2000).

77 Global market perceptions are heavily influenced by various business actors that supply information to the actors, including credit rating agencies which already include political risk, country risk ratings, as well as various reports and indexes published by the World Bank and other private institutions.

78 "Bolivia Submits a Notice under Article 71 of the ICSID Convention", 16 May 2007, http://icsid. worldbank.org/ICSID/FrontServlet?requestType=CasesRH\&actionVal=OpenPage\&PageType=Announcem entsFrame \&FromPage=NewsReleases \&pageName=Announcement3 (last access 23 July 2010).

79 "Ecuador Submits a Notice under Article 71 of the ICSID Convention", 9 July 2009, http://icsid. worldbank.org/ICSID/FrontServlet?requestType=CasesRH\&actionVal=OpenPage\&PageType=Announcem entsFrame\&FromPage=NewsReleases\&pageName=Announcement20 (last access 23 July 2010).

80 "Venezuela surprises the Netherlands with termination notice for BIT; treaty has been used by many investors to "route" investments into Venezuela", 16 May 2008, http://www.iareporter.com/ articles/20091001_93 (last access 23 July 2010).

${ }^{81}$ See UNCTAD World Investment Report 2010, published 22 July 2010, http://www.unctad.org/ Templates/WebFlyer.asp?intItemID=5535\&lang=1 (last access 1 August 2010). 
turtles and the fourth largest modern reptiles in the world, but specifically in Costa Rica, it is later observed that its population becomes endangered. In other words, what is previously not observable can become observable in the future also because of changes in technology and the ways of observation.

The bigger problems of uncertainty in social and environmental issues are one of uncertainty resulting from verifiability, even when the circumstances can already be determined. Many environmental problems are simply difficult to verify, thus rigid provisions in BITs narrows the room for discretionary judgment and limits differences in opinion. Lack of full scientific uncertainty mostly is the underlying problem, as acknowledged in the recognition of the precautionary principle. ${ }^{2}$ The European Commission Communication on the Precautionary Principle also notes that "[t]he precautionary principle applies where scientific evidence is insufficient, inconclusive or uncertain and preliminary scientific evaluation indicates that there are reasonable grounds for concern that the potentially dangerous effects on the environment, human, animal or plant health may be inconsistent with the high level of protection chosen by the EU."83 This is to emphasize the difficulties in determining the nature and the level of an environmental problem. That said, in event of insufficient, inconclusive, or uncertain scientific evaluation, no third parties including jurists (adjudicators or arbitrators) or expert panels (technical experts or scientists) would be able to reach a certain conclusion to verify the uncertainty even when the condition already emerges.

As far as investor-state dispute is concerned, the most relevant uncertainties are ones over effect. They are reflected in various ongoing debates and legal disputes in the international, regional, and national level. The debate over the economic impact of climate change represents the classic instance of these uncertainties. Environmental economists have long debated the economic effect of climate change ranging from the Stern Commission, ${ }^{84}$ to Lomborg, ${ }^{85}$ to Nordhaus, ${ }^{86}$ to Mendelsohn, ${ }^{87}$ and so forth. Suppose in response to the assessment developed by the Stern Commission which advocates sharp and immediate reductions on greenhouse gas emissions, Indonesia -a state with extensive rainforest that covers more than $15 \%$ of the global share- decides to suspend all natural resources licenses promised to the mining and extractive industry firms. ${ }^{88}$ The contract will be annulled, and parties must return to the

${ }^{82}$ See Rio Declaration on Environment and Development of 1992, "[i]n order to protect the environment, the precautionary approach shall be widely applied by States according to their capabilities. Where there are threats of serious or irreversible damage, lack of full scientific certainty shall not be used as a reason for postponing cost-effective measures to prevent environmental degradation." http://www.unep. org/Documents.multilingual/Default.asp?DocumentID=78\&ArticleID=1163 (last access 10 July 2010).

${ }^{83}$ Communication from the Commission on the Precautionary Principle, http://ec.europa.eu/ environment/docum/20001_en.htm (last access 10 July 2010).

${ }^{84}$ Nicholas Stern, "The Stern Review on the Economics of Climate Change", HM Treasury, London (2006).

${ }^{85}$ Bjorn Lomborg, The Skeptical Environmentalist: Measuring the Real State of the World, (Cambridge University Press, 2001).

${ }^{86}$ William D. Nordhaus, "A Review of the Stern Review on the Economics of Climate Change", "A Review of the Stern Review on the Economics of Climate", 45 Journal of Economic Literature 3 (2007), p. 686-702.

${ }^{87}$ Robert O. Mendelsohn, "A Critique of the Stern Report", 29 Regulation 4 (2006-2007), p. 42-46.

${ }^{88}$ The issue of large-scale crop-estates and open-pit mining in Indonesia's protected forests and peat lands have been one of the debated issues in dealing with deforestation and loss of the world's carbon stock. Pressure from international NGOs have called for suspending and terminating the existing contracts. Fore general overview, see Toni Johnson, "Deforestation and Greenhouse-Gas Emissions", Council on 
initial condition prior to the conclusion of the agreement. On the other hand, those firms argue that the measures are not economically justified by citing other studies to show that gradual -instead of sharp and immediate reductionsare sufficient to address the problem, and therefore, existing contracts must be respected. Determining the level of uncertainty will come down to debates over scientific results, and rigid provisions in BIT, or any contract for that matter, will not be optimal from an ex-post perspective.

\section{d. Strategic Behavior}

Analysis of strategic behavior of the potential host states, related to the choice between preference over strict provisions and flexible provisions, are developed upon the previous model of Guzman when analyzing the choice one must made between the "appropriate compensation" and that of "prompt, adequate, and effective" as mostly found in BITs. ${ }^{89}$ The structure is developed to provide a prisoner's dilemma model between potential host states that prevent collective action for demanding flexible provisions in BIT negotiation.

Several elements are modified herein. This situation assumes two possible alternative structures of an investment treaty. The first is the one that incorporates more flexibility to regulate social and environmental matters, and the other being one that incorporates strict requirement. If one only considers the economy of the host states, concluding a BIT with strict provision and less flexibility is inefficient, ${ }^{90}$ and they would be better off by not signing one. However, the host states also realize that the capital-exporting countries prefer BIT with strict provisions to the flexible ones because it provides more security and protection for their investors. It is also assumed that host states are competing for limited capital from the capital-exporting countries, ${ }^{91}$ in the sense that one's decision to allow more investment inflow to its country comes at the expense of the other potential host states as competitors. A country that signs BIT will have more institutional advantage over the ones that do not do so. Therefore, collectively potential host states are better off with forming a collusion not to sign BIT. However, individually, each has the incentive to attract capital and sign BIT.

Following Guzman's model, the framework of choice will be designed as a symmetric prisoner's dilemma of a one-shot game between two potential host states, as they can choose between cooperate (C) among each other by agreeing not to sign BIT and defect (D) by signing one while the other does not. Two conditions for the framework are:

- It is required that each player ranks her outcomes as follows:

$\mathrm{DC}>\mathrm{CC}>\mathrm{DD}>\mathrm{CD}$

- $\mathrm{CC} \geq \frac{\mathrm{DC}+\mathrm{CD}}{2}$

This is to make sure that mixed strategies are irrelevant.

Foreign Relations, http://www.cfr.org/publication/14919/deforestation_and_greenhousegas_emissions. html, 21 December 2009, (last access 15 July 2010).

${ }^{89}$ Sornarajah, supra note 18 , Guzman, supra note 11. See Sub-section B.I.

${ }^{90}$ Van Aaken, supra note 65. See Sub-section C.I.2.

${ }^{91}$ Guzman, supra note 11; Cristoph Engel, "Governments in Dilemma: A Game Theoretic Model for the Conclusion of Bilateral Investment Treaties", (University of St. Gallen Law and Economics Research Paper Series No. 2007-22, 2007). 
The pay-offs matrix of the modified model is illustrated below:

\begin{tabular}{|c|c|c|}
\hline & \multicolumn{2}{|c|}{ Prisoner 2} \\
\hline Prisoner 1 & No BIT & BIT \\
\hline No BIT & 4,4 & 0,6 \\
\hline BIT & 6,0 & $\underline{\mathbf{2}}, \underline{\mathbf{2}}$ \\
\hline \multicolumn{3}{|c|}{ Where $6>4>2>0$} \\
\hline
\end{tabular}

In a theoretical fashion, the only possible alternative to encounter this issue is that the potential host states establish cooperation among them to deny any offer made by capital exporting states that still incorporates strict provision. This would supposedly eliminate capital exporting states' ex ante benefit prior to treaty conclusion, being the advantage of choosing the most suitable country to invest its capital in. Should all potential host states stop competing against each other for the capital and start imposing the same conditions in the investment treaty negotiation, capital exporting states would have no alternative but to accept their offer.

However, no cooperation, coordination, arrangements, alliances, or any action for that matter ever appears in practice. At present there are recent trends of the proliferation of South-South BITs (BITs between developing countries, pursuant to which the fundamental assumption of "competing for capital" theory for rational of signing a BIT must be reframed), in addition to the increasing number of Economic Integration and Investment Agreements (EIIAs) concluded also between developing countries. ${ }^{92}$ These international agreements, however, do not cover rights and obligations over third party (capital-exporting country) and does not provide new institutional platform for cooperation.

High transaction costs can be associated with this dilemma. There should be substantially high number of potential host states for this cooperation to be effective, yet it would take only one country to defect in order to start the domino effect that would motivate other countries to defect as well. Suppose there are 10 potential host states, all of which have agreed to offer flexible provisions as non-negotiable clause in a BIT negotiation. Transaction costs will cover the negotiation costs and enforcement costs among all 10 of them. However, once one state defects, the others have the impulse also to defect, creating such costly cooperation very fragile to single defection, as the maintenance costs are ten times higher than the value it needs for starting defection.

\section{Benefit of BITs: Summing Up Empirical Studies}

Proponents of BITs remain convinced that the instruments have generated significant benefit, as such, any modifications (of incorporating non-economic interests such as environmental objectives) can hamper their designated purposes. This sub-section compiles various empirical works on BITs and concludes that BITs matter only if complemented by good domestic institutions

${ }^{92}$ Stephania Bonilla and Rosa Castro, "A Law-and-Economics Analysis of International Investment Agreements: Latin America", (Second Annual Conference of Societa Italiana di Diritto ed Economia 20-21 October 2006). 
perceived by foreign investors. The findings also negate the other extreme arguments supporting the views that BITs have very little impact. ${ }^{93}$

The real economic benefit of signing an investment treaty, especially for potential host states, remains debatable among economists and scholars. Many past empirical works on the economic significance of the growing number of BITs has produced contradictory findings concerning their impact on FDI. Meanwhile, the answer to this issue serves as an important foundation to analyze the bargaining power and power structure between the potential host states countries and the capital exporting states in investment treaty negotiations. If BITs do not have any significant impact on FDI, any effort to negotiate (and renegotiate) more flexible public interest provision, whatever the cost is, would then not justify the benefit.

Several respected findings will be introduced below to frame the empirical economic context. It is then concluded that these conflicting results are merely the result of neglecting the important political-economic backgrounds of concluding BITs. ${ }^{94}$ This argument supports the standing of the article that domestic political institutions matter in the structure of an international investment treaty.

Neumayer and Spess develop highly regarded and very robust empirical evidence with sophisticated methodology to suggest that developing countries enjoy potentially massive increases in FDI -up to 93\%- when signing BITs. Using components of the political risk index developed by the International Country Risk Guide (ICRG), they find that a country with relatively lower institutional quality benefits more from BITs. ${ }^{95}$ This finding conforms with the theory that BITs act as a substitute rather than a complement to the lower institutional quality of a country. Further, Salacuse and Sullivan conducted a cross-sectional empirical analysis on the impacts of US BITs and OECD BITs in developing countries. They found a strong positive relationship between BITs and FDI from the US to developing countries, but BITs with OECD countries are not significant. ${ }^{96}$

By contrast, using a different set of models and assumptions, HallwardDriemeier finds little evidence of this connection, that BITs play a minor role in stimulating greater FDI, and pursuant to which, BITs act more as complements than substitutes for good institutional quality and domestic property rights protection. Using 20 years of bilateral FDI flows from twenty OECD countries to 31 developing countries, the research finds that BITs are only effective in countries which are already in possession of high quality institutions and strong local property rights. They are, according to the ICRG political risk rating, countries with political risk of equal to 65 or above. ${ }^{97}$ Therefore, "only countries that are reforming and already have reasonably strong domestic institutions are most likely to gain from ratifying BIT." ${ }^{\prime 8}$

These results are similar to those found by Tobin and Rose-Ackerman in

\footnotetext{
${ }^{93}$ Sornarajah, supra note 18 , argues that "stability and other factors have a greater influence on investment flows than do investment treaties."

${ }_{94}$ Tobin and Rose-Ackerman, supra note 76.

${ }^{95}$ Eric Neumayer and Laura Spess, “Do Bilateral Investment Treaties Increase FDI to Developing Countries?", 33 World Development 10 (2005), p. 1567-1585.

${ }^{96}$ Jeswald W. Salacuse and Nicholas P. Sullivan, "Do BITs Really Work? An Evaluation of Bilateral Investment Treaties and Their Grand Bargain," 46 Harvard International Law Journal (2005), p. 67-130.

${ }^{97}$ Mary Hallward-Driemeier, "Do Bilateral Investment Treaties Attract FDI? Only a Bit.. And They Bite”, (World Bank Policy Research Working Paper No. 3121. 2003).

${ }^{98}$ Hallward-Driemeier, supra note 97.
} 
their first study that also finds this little correlation. ${ }^{99}$ Examining BITs signed with the US, they argue that the relationship between BITs and FDI is very weak, and that BITs only play a major role in countries where the investment environment has already been improved. According to their research, BITs by themselves, do not serve as a signal of a secure investment environment in host states, and they only have a positive effect on FDI flows in countries which are already in stable condition of business environment.

There are a number of possible explanations for the differences in these results, which are obviously caused by the differences in methodology and research design. Tobin and Ackerman's first research has noticed this problem when comparing their result with that of Salacuse and Sullivan's. This includes differences in the dataset, in the variables, in the time frame coverage. They also argue that the selection of sample size creates their different result with Neumayer and Spess, while it is also admitted that their research omitted major countries including South Korea, China, and Central and Eastern European Countries. Meanwhile, Neumayer and Spess claim that Hallward-Driemeier fails to detect the signaling effect and lacks representative sample; while the work of Salacuse and Sullivan is cross-sectional that it falls short when detecting the direct impact. However, they cannot elaborate their extremely different outcome with that of Tobin and Ackerman.

The second work of Tobin and Rose-Ackerman attempts to converge the conflicting findings of previous studies by highlighting the way the political environment may interact with BITs to influence the level of FDI. The significance of the updated work of Tobin and Ackerman is that, both theoretically and empirically, BITs cannot be judged in isolation. Each of the discussed papers assumes that the effect of BITs on FDI flows is an independent aspect of the broader political and economic environment, while "their impact on host state FDI flows must be studied within the context of the political, economic and institutional features of the host state". 100

This indicates that BITs cannot attract FDI by themselves, it must take into account other determining environments. They argue that risky investment environment due to dysfunctional government might permit foreign investors to opt out of domestic institutions through BITs. However, foreign investors are unlikely interested in prtnership with governments of very weak governance practices. Rather than being substitutes, "improvements in the political environment for investment are likely to complement BITs and further enhance their impact."101 Therefore, on balance, BITs will have a positive interaction with the underlying political determinants of investment.

Their econometric models display that as a country's political environment for investment improves, the impact of signing an additional BIT increases. The figure below provides greater understanding of this preposition. ${ }^{102}$

For countries with good investment environments and strong politicaleconomic environments such as Malaysia and Chile, an additional BIT always has a positive impact on estimated flows of FDI, until they decrease in response

${ }^{99}$ Jenifer Tobin and Susan Rose-Ackerman, "FDI and the Business Environment in Developing Countries: the Impact of Bilateral Investment Treaties", (Yale Law \& Economics Research Paper No. 293, 2005).

\footnotetext{
${ }^{100}$ Tobin and Rose-Ackerman, supra note 76.

101 Tobin and Rose-Ackerman, supra note 76.

102 The graph is formulated by Tobin and Rose-Ackerman, supra note 76.
} 
to the total number of BITs in the world. However, for countries with weaker political-economic and investment environments, this positive impact is increasingly smaller (say Georgia and Malawi), with those in the lowest part, say Sudan and Afghanistan, reaching a point of zero impact even before the number of existing BITs in the world arrives at the maximum level. This support the hypo article that only the most developed of the developing countries, thus with mediocre political risk, gain positive impact from signing additional BITs according to the findings. ${ }^{103}$ In conclusion, only with a broader understanding of the political-economic environment one can fully understand the impact of BIT programs on FDI flows.

As a further complementary study, Aisbett finds conformity with the work of Tobin and Ackerman by introducing a new concept of endogenous relationship between investment flows and the investment treaties to disentangle causation from correlation. ${ }^{104}$ Aisbett employs a simple model to show empirical econometric evidence that BIT participation is endogenous -as opposed to the exogenous effect from BITs - and may be driven by omitted variables such as a change in the domestic policy environment of the host. The model also shows the potential for reverse causality, where a higher growth rate of FDI leads to increased probability of a BIT being formed.

Having concluded the above finding, the article takes the standpoint that BITs matter. Otherwise, there is no need to discuss change or renegotiation of new provision in BITs related to public interest, because it would nevertheless fail to render the positive impact one would expect. However, this positive impact is attributed to the domestic institutions, and how the interplay between BITs and host states' domestic institutions define the political risks of direct investing as perceived by foreign investors.

Another issue left unanswered in the economic impact, in relation to the flexibility of BITs and the incorporation of social and environmental clauses, is the cost of BITs. This is acknowledged by Neumayer and Spess, a few of BITs optimists, as follows:

"whether the demonstrated benefits of signing BITs in the form of increased FDI inflows are higher than the substantial costs, - which developing countries incur in negotiating, signing, concluding, and complying with the obligations typically contained in such treaties -, is impossible to tell. What we do know is that BITs fulfill their purpose, and those developing countries that have signed more BITs...are likely to receive more FDI in return."105

BITs are not costless. Resources are expended on the design, negotiation, and enforcement of BITs. "When ratifying BITs, host states sacrifice policy flexibility and risk sizable fines and legal costs if they are sued by an investor."106

103 The same conclusion is reached for membership in international organizations in general, that signaling effect for foreign investments works best for countries with mediocre risk ratings. See Axel Dreher, Heiner F. Mikosch, and Stefan Voigt, "Membership in International Organizations as a Signaling Device for Foreign Investors", Membership in International Organizations as a Signaling Device for Foreign Investors", (3rd Annual Conference of the Political Economy of International Organizations 28-30 January 2010).

${ }^{104}$ Emma Aisbett, "Bilateral Investment Treaties and Foreign Direct Investment: Correlation versus Causation", (Munich Personal RePec Archive, 2007).

${ }^{105}$ Neumayer and Spess, supra note 95.

${ }^{106}$ Aisbett, supra note 104. 


\section{Foreign Investors' Choices : International and Domestic Law Dynamics}

\section{The Route to Foreign Investors' Choices}

I would like to reiterate several key points I have elaborated above as follows. Firstly, the standard model that emphasizes on the dynamic time inconsistency problem of the host states do no longer hold up in the present global economic environment. The incentives between the parties are always considered as conflicting, and the potential host states have the incentive to commit opportunistic behavior to expropriate the foreign investors' assets. BITs are then expected to bolster the credibility of host states' commitments, thereby mitigating the inconsistency problem and promoting FDI. This, however, does not take into consideration the cooperative interests of the parties, the reiterated games played, and the differences in nature between the actors.

Secondly, the standard model also fails to capture the importance of domestic institutions, as already demonstrated in empirical studies, as well as the continuous bargaining at the domestic level. Domestic institutional matters and foreign investors' capacities to influence domestic institutions will determine the bargaining outcome. Thirdly, the incorporation of strict provisions in BITs concerning social and environmental protection disregard the costs imposed by those provisions on the ability of the host states to enact benevolent regulations for social and environmental purpose. It also does not accommodate the uncertainty over the observability and verifiability of social and environmental affairs, which despite technological advancement, often sparks technical debates among the experts.

Fourthly, it is impossible for the potential host states to ask for better provisions in BIT that incorporate more flexible social and environmental discretionary power, because they lack credible bargaining power in BIT negotiation. BITs serves not only as protection device for foreign investors but also as signaling device of the host states about their willingness to integrate in the global economy and represent the general economic environment of the host states. Violation against BITs incurs excessive reputational costs by means of network externalities and makes any threat of host states to exit the system not credible, because it does not arise to the level of efficient breach.

Lastly, the recent phenomenon of several capital exporting states offering more flexible provisions in their signed and/or model BITs suggest that the only possible route for flexible social and environmental provisions to flourish is through structuring the incentives of the capital exporting states.

All of these are developed to frame the answers to the question asked as the starting point of the article: under what condition a capital exporting state could introduce higher flexibility for regulating social and environmental affairs in a BIT negotiation?

\section{Issue Linkage: International and Domestic Law Trade-Off}

With due observance of the importance of domestic institutions, capital exporting states would introduce higher flexibility on social and environmental affairs when they (and the foreign investors on which behalf they act) manage to link the potential benefit (or utility) derived between BIT protection and access to domestic lawmaking. 
The only alternative for foreign investors to retain their ex ante bargaining power is to gain access to legal and regulatory making in the host states' domestic legal environment, ensuring that the domestic legal system will take their interests into account. The degree of openness of that access is of paramount importance in BIT negotiation.

There are many evidences to demonstrate this. Around 25 percent of FDI made by privately-owned firms in the global electricity and power generating industry during the 1990s were into countries that ranked in the top quartile of policy risk. ${ }^{107}$ Further, following the wave of nationalizations in the early 1970s in Chile, a study of the copper industry found that the firms which developed domestic and transnational alliances were successful in getting full compensation for nationalized assets, while those who did not form domestic alliances were not. ${ }^{108}$ Kobrin also found evidence that host states refrain from conducting any opportunistic behaviors against firms in the manufacturing industries, particularly in high technology sectors. ${ }^{109}$

Bennett and Sharpe even suggested a reverse OBM incentive structure in the Mexican automotive sectors. The Mexican government's bargaining power was strongest ex-ante because of the huge market. Ex-post, as foreign firms had become integrated into the Mexican economy and developed strong relationships with local firms, their bargaining power increased rather than obsolesced. The continuous flow of the promised technology transfers further kept host states dependent on the foreign investors. ${ }^{110}$

The above exemplifies the advantages that foreign investors made to retain their bargaining power. On the host states' side, Chile is the country that managed to pursue their interests at the domestic level without committing opportunistic acts in the international level. While BITs limit many of their governmental capacity, including environmental regulation, Chile pursues these at the domestic deal level, rather than requiring them. They bargain hard to ensure that the environmental practices of firms are reviewed, that linkages to the local economy will be created and so forth. ${ }^{111}$

This analysis suggests that capital exporting states (hereby denoted as "C") are faced with three legal policy alternatives to secure the investment of their constituent foreign investors: (1) protection under BITs (hereinafter " $\mathrm{P}_{\mathrm{C}}$ ") or (2) access to influence legal and regulatory making (hereinafter " $A_{C}$ "), or (3) the combination of both, with which composition the same level of utility is generated. Assumption is made that foreign investors will always prefer the third option (combination) because the risks will be distributed between

${ }^{107}$ Guy L. F. Holburn and Bennet A. Zelner, "Policy Risk, Political Capabilities and International Investment Strategy: Evidence from the Global Electric Power Industry”, Strategic Management Journal 31 (2010).

108 Theodore Moran, "Transnational Strategies of Protection and Defense by Multinational Corporations: Spreading the Riskand Raising the Cost for Nationalization in Natural Resources", International Organization 27 (1973), p. 273-87; see also Theodore Moran (ed.), Multinational Corporations: The Political Economy of Foreign Direct Investment, (Lexington Books, 1985).

${ }^{109}$ Stephen J. Kobrin, "Testing the Bargaining Hypoarticle in the Manufacturing Sector in Developing Countries", 41 International Organization, 4 (1987), p. 609-638.

${ }^{110}$ Douglas C. Bennett and Kenneth E. Sharpe, "Agenda Setting and Bargaining Power: The Mexican State Versus Transnational Automobile Corporations”, World Politics 32 (1979), p. 57-89.

${ }^{111}$ See interview with Kevin P. Gallagher in Damon Vis-Dunbar and Henrique Suzy Nikiema, “Do Bilateral Investment Treaties Lead to More Foreign Investment?", 30 April 2009, http://www. investmenttreatynews.org/cms/news/archive/2009/04/30/do-bilateral-investment-treaties-lead-tomore-foreign-investment.aspx (last access 3 August 2010). 
the two available institutions, and it enables the investor to resort to another channel, should one exogenous shock over the other emerges. The greater the BITs protection, the lesser a foreign investors need to have access to domestic legal and regulatory making. In contrast, if the investor has already obtained sufficient access to legal and regulatory making, then the benefit from having strict BIT protection decreases.

While the choices between them can generate different utility level, the combination that generates the same can be placed into one single indifference curve of foreign investors' preferences. The increase in level of utility is simply for the purpose of ordering/ranking the bundle of goods (ordinal approach). The level of $\mathrm{P}_{C}$ is measured by the level of property rights protection of the foreign investors; and the level of $A_{C}$ is measured by the degree of openness of domestic legal institutions -as will be further elaborated in the next sub-section. The closer the Indifference Curve (IC) to the origin, the lesser utility it generates. And as combination is always preferred to one extreme option, the curve is convex to the origin.

Now the preferences of a potential host state are also incorporated in the model (hereby denoted as " $\mathrm{H}^{\prime \prime)}$. Host states also have preferences among: (1) protection under BITs (hereinafter " $P_{H}$ ") or (2) access to influence legal and regulatory making (hereinafter " $A_{H}$ "), or (3) the combination of both, with which composition the same level of utility is generated. Indifference curves which display various levels of utility of Host states can also be portrayed into the graph.

Remember that the previous theory that is solely based on the international level of protection under BITs only manages to explain the tradeoff between strict and flexible provisions, that is to say that only the flexible ones will be welfare enhancing jointly for both parties. The rationale for negotiation and exchange is not incorporated and it requires other models, namely the competitive pressure that results in strategic behavior and transaction costs approach, to explain why potential host states are willing to enter into BIT that incorporates strict provisions.

The following illustration based on the Edgeworth Box analysis. However, ${ }^{112}$ itfurtherincorporates the trade-offbetween international protection (whether strict or flexible) and domestic access to lawmaking (whether open or closed), as the explanatory variables and demonstrates that Pareto improving exchange between capital exporting states and host states, is possible.

Suppose there are two parties negotiating a BIT, a capital exporting state and a potential host state. The red line signifies ICs for the capital exporting state and the blue lines for potential host state. ICs with bold contour, both the red $\left(\mathrm{C}_{3}\right)$ and blue ones $\left(\mathrm{H}_{3}\right)$, represent the minimal capacity necessary for the negotiation to start in the first place. Say, a country that wants to attract an investment but cannot signal credibility in the international level and does not have the resources to open up its access to domestic lawmaking will not be able to find a partner who is willing to enter into a BIT with the country in question. The yellow colored lens-shaped area between $\mathrm{C}_{3}$ and $\mathrm{H}_{3}$ represents the set of feasible agreements. Any agreement reached inside the area will make one of the parties better off without making another worse off. The dotted line of $B_{C}$

112 The model is inspired by the work of Robert D. Putnam, "Diplomacy and Domestic Politics: The Logics of Two Levels Game”, 42 International Organization 3 (1988), p. 427-460. 
and $\mathrm{B}_{\mathrm{H}}$, being the budget lines, are the minimum budget that must be invested by states, should they want to have Pareto improving exchange in the BIT market.

Although additional subtleties (such as the nature of the "contract curve" at which the Pareto optimal point is found) might be further extracted, the main argument from this type of analysis is simple: the possibility of package deals between international and domestic law opens up a rich array of strategic alternatives for the negotiating parties in the BIT bargaining game.

\section{Determinants for Changes in Foreign Investors' Preferences}

Pursuant to the illustration above, from the foreign investor's perspective there are several changes that can affect the bargaining power and position in a BIT negotiation, the structure for which is channeled through the preferences of the capital exporting state.

Firstly, changes in foreign investor's capabilities in gaining access to domestic legal and regulatory making. A foreign investor can accumulate and have better knowledge about a host state's domestic legal system because of learning effect from the previous investment or because of institutional distances (that countries with more institutional features of the capital exporting state will be easier to gain access to). ${ }^{113}$ The knowledge will push forward the preference curve but remains in the area of feasible agreements, as portrayed by the graph below.

The change in the foreign investor's subjective capabilities is exemplified by the shift of the green dotted line of budget line from BC to BC'. The change pushes the IC of capital exporting states from C3 to C3'. Although the new IC of C3' remains within the area of feasible agreements, the size is greatly reduced. This is because of the foreign investor's confidence on its stronger bargaining position. Should the host state intends to behave opportunistically, the foreign investor will immediately gain access to the domestic legal system.

Secondly, changes in the objective degree of openness of access to legal and regulatory making will also affect the bargaining position. Concrete examples include judicial reform initiatives that increase judicial transparency and eradicate judicial corruption, thus enhancing domestic court's capabilities and capacities to adjudicate matters properly. The graph below portrays change due to decrease in price of access to legal and regulatory making.

Again, as the increase in the degree of openness of access to legal and regulatory making might reduce demand of the foreign investor in the international level of BIT negotiation, foreign investors in fact gain better bargaining advantage, because they will secure in the domestic level, so the cost of "no-agreement" or vetoed at the international level will be cheaper. The foreign investor, consequently, will play the hawk/dove game against the host state, ${ }^{114}$ a game that will not risk losing because of the domestic advantage.

Thirdly, the foreign investor can advance its bargaining power if the price of BIT protection is cheaper. One of which includes, for instance, that the international investment jurisprudence in investor-state arbitration concerning social and environmental protection has become more stable and predictable

\footnotetext{
${ }^{113}$ Holburn and Zelner, supra note 107.

114 The smaller the win-set options for one party, the smaller the cost for veto or "no-agreement", and consequently the more credible one's demand in a negotiation. Putnam, supra note 112; Thomas Schelling, The Strategy of Conflict, (Harvard University Press, 1981).
} 
with clear legal principles that can be derived out of them. This will greatly increase the level of predictability of investor-state arbitration.

The graph above depicts the cost reduction of protecting the foreign investor through BIT. The cost reduction increases the utility of the foreign investor, consequently increasing its expected benefit at the domestic level. Nevertheless, despite its push for more open access to legal and regulatory making at the domestic level, it does require more cost to persist on that issue. And despite the effort is falling within the budget line of the foreign investor, one possible explanation about one might not pursue at the domestic level even further is one of opportunity costs that might be better allocated to other area.

\section{Organization of Legal System and Foreign Investors' Choices}

Having discussed previously about the role of access to legal and regulatory making and the trade-off foreign investors must make, the next issue would be what exactly the meaning of the term is. In short, how to define the degree of openness of access to legal and regulatory making? This sub-section briefly seeks to identify and further scrutinize which legal institutions matter and how domestic legal processes affect investor perceptions, toward which end I call for better definitions of the interplay, a conceptual structure relating domestic legal institutions to a foreign firm, and information about the role of domestic legal institutions.

The degree of openness is the extent to which foreign investors can influence the legal and regulatory decision making within the host state's domestic legal system. This perspective emphasizes on the objective features of the legal system that can be used by foreign investors to pursue their interests, and not on the foreign investors' subjective capabilities in such recourse. For example, the division of power between the central and local government concerning the authority to issue social and environmental regulation; whether the legislative structure allows organized civil societies and interest groups to voice their opinions; whether the highest court is independent from the executive's influence; whether the national authorities (executive or judiciary) have strong influence over lawmaking at the local level; and so forth. ${ }^{115} \mathrm{~A}$ subjective approach, by contrast, implies the use of certain criteria subjectively tailored and considered as the necessary institutional endowments for foreign investors. These include various institutional risk assessments or rule of law measurement projects such as the International Country Risk Guide (ICRG) or The World Bank's Ease of Doing Business.

The best starting point for dissecting the objective features is a general comparative legal study that compares various legal systems in the world. The classic method of comparison, at least as far as the Western legal origin is concerned, is the distinction between common law and civil law legal system. Many, nevertheless, have come to the conclusion that this distinction is no longer relevant in practice and the operation of law is far more complex. Judges in a civil law country often adhere to previous legal decisions, though not necessarily binding, while legislators in a common law country have enacted various legal principles by means of legislations, reducing the role of the judiciary. ${ }^{116} \mathrm{~A}$

${ }^{115}$ For a general discussion, see Stefan Voigt, "How to Measure the Rule of Law", (MAGKS Papers on Economics, 2009).

${ }^{116}$ Curtis J. Milhaupt and Katharina Pistor, Law and Capitalism: What Corporate Crises Reveal About 
new way of comparing legal system is better suited by determining whether lawmaking process is centralized or decentralized.

This new distinction is related not only to the level of legal and regulatory making (whether national or local), but most importantly measured by the number of actors involved, too. In a highly concentrated system, few actors are involved in the lawmaking, as in a decentralized system, greater range of opportunities is provided for actors to participate in lawmaking and enforcement. ${ }^{117}$ This distinction of legal system based on locus of decision making is also discussed by others, including Glaeser and Shleifer, ${ }^{118}$ Damaska, ${ }^{119}$ and Milhaupt and Pistor. ${ }^{120}$

That being said, a foreign investor's access to legal and regulatory making of the host state depends as to whether the legal system of the host is centralized or decentralized. In a centralized system, law is mostly driven by regulations as opposed to litigation. In practice only limited number of actors can have access to the legislative body because the structure and method of the civil societies organized to raise the subject matter will determine the outcome. ${ }^{121}$ Litigation driven lawmaking, or private ordering, is more decentralized and allows more actors to participate in the process, and the law emerges out of spontaneous order via Hayek's bottom-up adaptation by means of adjudication. ${ }^{122}$

However, to point out that one system is better or more efficient than the other simply disregard the institutional context and different responses of the affected parties (i.e. foreign investors) in the respective system. Concrete example is China which has become the main attraction for FDI although the legal and regulatory making is highly centralized and concentrated in the hands of the Communist Party officials and bureaucrats. ${ }^{123}$ The capabilities of foreign investors doing business in China signify their adaptation to a centralized legal decision making environment, as opposed to doing business in the United States with more decentralized system. There are other examples that show foreign investors' preferences over centralized system because it provides stability, such as case of the increase of FDI in Chile or Indonesia during their authoritarian regime. ${ }^{124}$

In a centralized legal system, the mechanism operates through legislative, regulatory, and policy making process, whereby interest groups attempt to influence political actors seeking to retain public office within the constraints imposed by a formal structure. The main agents of change in an emergent institution are the organized interest groups. ${ }^{125}$ In a decentralized legal

\footnotetext{
Legal Systems and Economic Development Around the World, (University of Chicago Press, 2008).

${ }^{117}$ Milhaupt and Pistor, supra note 116.

${ }^{118}$ Edward L. Glaeser and Andrei Shleifer, "Legal Origins", 4 Quarterly Journal of Economics 117 (2002), p. 1193-1229.

${ }_{119}$ Mirjan Damaska, "Structures of Authority and Comparative Criminal Procedure", Yale Law Review 84 (1975); Milhaupt and Pistor, supra note 116.

${ }^{120}$ Milhaupt and Pistor, supra note 116.

${ }^{121}$ Milhaupt and Pistor, supra note 116.

${ }^{122}$ Friedrich A. Hayek, The Road to Serfdom, (Chicago University Press, 1944).

${ }^{123}$ Yingyi Qian. "The Institutional Foundations of China's Market Transition”, (Stanford University Economics Department Working Paper 99-011, 1999); Jean C. Oi and Andrew G. Walder (eds.), Property Rights and Economic Reform in China, (Stanford University Press, 1999).

${ }^{124}$ See John R. Oneal, "The Affinity of Foreign Investors for Authoritarian Regimes", 47 Political Research Quarterly 3 (1994), p. 565-588.

${ }_{125}$ See Gary Becker, "A Theory of Competition among Pressure Groups for Political Influence", The Quarterly Journal of Economics 98: p. 371-400 (1983); George J. Stigler, Citizen and the State: Essays on
} 
system, by contrast, the mechanism operates through "creative destruction" of legal principles, from one court decisions into another influenced by legal professionals of judges, lawyers, prosecutors, law enforcement agencies, and other relevant parties. These parties also compete to influence the outcome of the law.

A centralized legal system is ex-ante unpredictable and unstable. However, once a foreign investor manages to gain access and influence over the main actors, the ex-post outcome will be predictable and stable. A decentralized legal system is ex-ante predictable and stable because it provides a clear rule of the game for many players to interact in such system. Nevertheless, the ex-post outcome is unpredictable and unstable due to the rapid pace of the creative destruction. Organizing interest groups is preferred if the system is centralized, and investing in litigation skills if the system is decentralized, or by the combination of both.

These differences in the organization of legal system make defining and measuring the "degree of openness" very complex. Domestic legal system must not be considered as institutional endowment; rather dynamic relationship with the foreign investors, being one will influence the other, and vice versa. Foreign investors will always assess their own capabilities to cope with these institutional differences prior to entering a market for FDI. Furtherance to their assessment, and if the decision to enter the market is taken, they will always have to maintain, manage, and deal with all of the institutional risks and all changes that occur therein. This is not covered in the article, and will be a good design for the consequent research agenda.

\section{Conclusion}

As a response to the question of which condition that would allow a capital exporting state to introduce higher flexibility for regulating social and environmental affairs in a BIT negotiation, the article offer the answer on issue linkage between the following issues: 1). the level of protection under BIT; 2). the degree of openness of access to domestic legal and regulatory making of the host state and 3). the foreign investor's capabilities to deal with the tradeoff. Ceteris paribus, the linkage enables a set of feasible Pareto improving deals out of BIT negotiation. Foreign investor will no longer require a strong level of protection by means of strict BIT provisions concerning the host state's right to regulate social and environmental matters if it succeeds to manage in gaining access to the domestic legal system of the host state, which subject conditionally to the legal system's degree of openness. This implies a two-level trade-off, namely with regard to the BIT provisions (strict vs. flexible) and the access to domestic legal system (open vs. closed).

The informal model offered in the article is a dynamic one because it is not only incorporating the objective views on the level of BITs protection and the domestic legal system's degree of openness, but also the subjective capabilities of foreign investors to make the trade-off and their respond to exogenous change. At the domestic level, this means that the degree of openness affects foreign investors' preferences, but foreign investors will also try to influence the structure of the legal system.

Regulation, (University of Chicago Press, 1975). 


\section{Bibliography}

\section{Legal and Formal Documents}

Canada Model Foreign Investment Promotion and Protection Agreement, http:// www.international.gc.ca/trade-agreements-accords-commerciaux/agracc/fipa-apie/index.aspx (last access 25 July 2010)

Compañía del Desarrollo de Santa Elena S.A. v. Republic Of. Costa Rica, (ICSID Case No. ARB/96/1; 17 February 2000)

Ethyl Corporation v. Canada (NAFTA Tribunal Preliminary Award on Jurisdiction, 24 June 1998)

EuropeanCommission,Communicationfrom the CommissiononthePrecautionary Principle, http://ec.europa.eu/environment/docum/20001_en.htm (last access 10 July 2010)

Metalclad Corporation v. United Mexican States (NAFTA Tribunal Decision 30 August 2000)

Methanex v. United States (NAFTA Tribunal Final Decision, 3 August 2005)

Norwegian Model Agreement for the Protection and Promotion of Investments, (http://ita.law.uvic.ca/documents/NorwayModel2007.doc (last access 25 July 2010)

S.D. Myers, Inc. v. Canada, (NAFTA Tribunal, Partial Award, 13 November 2000) Técnicas Medioambientales Tecmed, S.A. v. United Mexican States (ICSID Award Case No. ARB(AF)/00/2)

United Nations (UN) General Assembly (GA) Resolution No. 1803 on Permanent Sovereignty Over Natural Resources G.A. res. 1803 (XVII), 17 U.N. GAOR Supp. (No.17) at 15, U.N. Doc. A/5217 (1962)

United Nations (UN) General Assembly (GA) Resolution No. 3171 on Permanent Sovereignty Over Natural Resources G.A. res. 3171 (XXVIII), 28 U.N. GAOR Supp. (No.30) at 52, U.N. Doc. A/9030 (1974)

United Nations (UN) General Assembly (GA) Resolution No. 3201 on New International Economic Order G.A. res. 3201 (VI), 6 U.N. GAOR Supp. (No.1) at 3, U.N. Doc. A/9559 (1974).

UNEP, Rio Declaration on Environment and Development of 1992. http://www. unep.org/Documents.multilingual/Default.asp?DocumentID=78\&Article ID=1163 (last access 10 July 2010)

United States Model BIT 2004, http://www.state.gov/documents/ organization/117601.pdf (last access 2 August 2010).

US-Australia Free Trade Agreement, signed on 1 March 2004

US-Chile Free Trade Agreement, signed on 6 June 2003

US-Central America Free Trade Agreement (CAFTA), signed on 28 January 2004

US-Morocco Free Trade Agreement, signed on 15 June 2004

Vienna Convention on the Law of Treaties, adopted 22 May 1969, entered into force 27 January 1980, UN Doc. A/Conf.39/27; 1155 UNTS 331; 8 ILM 679 (1969); 63 AJIL 875 (1969) 


\section{Books, Journals, and Other Scientific Documents}

Aisbett, Emma. "Bilateral Investment Treaties and Foreign Direct Investment: Correlation versus Causation". (Munich Personal RePec Archive, 2007)

Alford, Roger P. and Rogers, Catherine (eds.). The Future of Investment Arbitration. (Oxford University Press, 2009)

Bar-Gil, Oren and Ben-Shahar, Omri. "Threatening an Irrational Breach of Contract". Michigan Law and Economics Research Paper No. 02-016 (2002)

Becker, Gary. "A Theory of Competition among Pressure Groups for Political Influence". The Quarterly Journal of Economics 98: p. 371-400 (1983)

Bennett, Douglas C. and Sharpe, Kenneth E. "Agenda Setting and Bargaining Power: The Mexican State Versus Transnational Automobile Corporations". World Politics 32 (1979), p. 57-89.

Bjorklund, Andrea K. “The Necessity of Sustainable Development?", in Seger, Marie-Claire Cordonnier, Gehring, Markus and Newcombe, Andrew (eds.). Sustainable Development in World Investment Law. (Kluwer Law International, forthcoming 2009/2010)

Bjorklund, Andrea K. "Emergency Exceptions: State of Necessity and Force Majeure", in Muchlinski, Peter, Ortino, Federico and Schreuer, Christoph (eds). The Oxford Handbook of International Investment Law. (Oxford University Press, 2008)

Bonilla, Stephania and Castro, Rosa. "A Law-and-Economics Analysis of International Investment Agreements: Latin America". (Second Annual Conference of Societa Italiana di Diritto ed Economia 20-21 October 2006)

Chalamish, Efraim. "The Future of Bilateral Investment Treaties: A De Facto Multilateral Agreement". 34 Brooklyn Journal of International Law 2 (2009)

Coase, Ronald H. "The Problem of Social Cost". 3 Journal of Law and Economics 1 (1960)

Damaska, Mirjan. "Structures of Authority and Comparative Criminal Procedure". Yale Law Review 84 (1975)

Dreher, Axel, Mikosch, Heiner F. and Voigt, Stefan. "Membership in International Organizations as a Signaling Device for Foreign Investors? Membership in International Organizations as a Signaling Device for Foreign Investors". (3rd Annual Conference of the Political Economy of International Organizations 28-30 January 2010)

Dolzer, Rudolf and Stevens, Margrete. Bilateral Investment Treaties. (Brill, 1995).

Dunning, John H. "Governments and Multinational Enterprises: From Confrontation to Cooperation?". In Eden, Lorraine and Potter, Evan (eds.). Multinationals in the Global Political Economy. (Macmillan, 1993)

Dunning, John H. "Location and the Multinational Enterprise: A Neglected Factor?”. 29 Journal of International Business Studies 1 (1998), p. 45-66. 
Eden, Lorraine and Lenway, Stefanie. "From Obsolescing Bargain to the Political Bargaining Model", in Robert Grosse (ed.). International Business and Government Relations in the 21st Century (Cambridge University Press, 2005)

Elkins, Zachary, Guzman, Andrew T. and Simmons, Beth A. "Competing for Capital: The Diffusion of Bilateral Investment Treaties, 1960-2000". International Organization 60 (Fall 2006): p. 811-846.

Engel, Cristoph. "Governments in Dilemma: A Game Theoretic Model for the Conclusion of Bilateral Investment Treaties". (University of St. Gallen Law and Economics Research Paper Series No. 2007-22, 2007)

Epstein, Richard A. Takings: Private Property and the Power of Eminent Domain. (Harvard University Press, 1985)

Fischel, William A. Regulatory Takings: Law, Economics, and Politics. (Harvard University Press, 1995)

Fagre, Nathan and Wells, Louis T. "Bargaining Power of Transnationals and Host Governments". 13 Journal of International Business Studies, 13(1982), p. 9-23.

Ginsburg, Tom. "International Substitutes for Domestic Institutions: Bilateral Investment Treaties and Domestic Governance". International Review of Law and Economics 25 (2005)

Glaeser, Edward L. and Shleifer, Andrei. "Legal Origins". 4 Quarterly Journal of Economics 117 (2002), p. 1193-1229.

Goetz, Charles and Scott, Robert. "Liquidated Damages, Penalties, and the Just Compensation Principle: A Theory of Efficient Breach". 77 Columbia Law Review 554 (1977)

Greif, Avner. Institutions and the Path to the Modern Economy: Lessons from Medieval Trade (Political Economy of Institutions and Decisions), (Cambridge University Press, 2006)

Guzman, Andrew T. How International Law Works. (Oxford University Press: 2007)

Guzman, Andrew T. "Why LDCs Sign Treaties That Hurt Them: Explaining the Popularity of Bilateral Investment Treaties". Virginia Journal of International Law 38 (1998): p. 639-688.

Hallward-Driemeier, Mary. "Do Bilateral Investment Treaties Attract FDI? Only a Bit.. And They Bite". (World Bank Policy Research Working Paper No. $\underline{3121}, 2003)$

Hayek, Friedrich A. The Road to Serfdom. (Chicago University Press, 1944)

Henisz, Witold J. "Institutional Environment for Multinational Investment". 16 Journal of Law, Economics, and Organization 2 (2000), p. 334-364.

Henisz, Witold J. and Zelner, Bennet A. "Legitimacy, Interest Group Pressures and Institutional Change: The Case of Foreign Investors and Host Country Governments". (William Davidson Institute Working Paper Number 589, 2003)

Holburn, Guy L. F. and Zelner, Bennet A. "Policy Risk, Political Capabilities and International Investment Strategy: Evidence from the Global Electric Power Industry". Strategic Management Journal 31 (2010) 
Jakobsen,Jo. “Does Democracy Moderate the Obsolescing Bargaining Mechanism? An Empirical Analysis 1983-2001". available at http://www.unctad.org/ en/docs/iteiit20063a3_en.pdf (last access 20 July 2010)

Johnson, Toni. "Deforestation and Greenhouse-Gas Emissions". Council on Foreign Relations. http://www.cfr.org/publication/14919/deforestation and_greenhousegas_emissions.html, 21 December 2009. (last access 15 July 2010)

Kalderimis, Daniel. "Investment Treaties and Public Goods". (Presentation to AIELN Conference, Tokyo, 2009)

Kaplow, Louis. "An Economic Analysis of Legal Transitions". 99 Harvard Law Review 511 (1986)

Kobrin, Stephen J. "Testing the Bargaining Hypoarticle in the Manufacturing Sector in Developing Countries". 41 International Organization, 4 (1987), p. 609-638.

Kriebaum, Ursula. "Regulatory Takings: Balancing the Interests of the Investor and the State". 8 The Journal of World Investment and Trade (2007), p.717744.

Luo, Yadong. "Toward a Cooperative View of MNC-host Government Relations: Building Blocks and Performance Implications". Journal of International Business Studies 32 (2001), p. 401-19.

Lomborg, Bjorn. The Skeptical Environmentalist: Measuring the Real State of the World. (Cambridge University Press, 2001)

Mendelsohn, Robert 0. "A Critique of the Stern Report". 29 Regulation 4 (20062007), p. 42-46.

Milhaupt, Curtis J. and Pistor, Katharina. Law and Capitalism: What Corporate Crises Reveal About Legal Systems and Economic Development Around the World. (University of Chicago Press, 2008)

Miceli, Thomas J. and Segerson, Kathleen. "Takings", (1999) in Encyclopedia of Law and Economics, available at http://encyclo.findlaw.com/6200book. pdf

Moran, Theodore. "Transnational Strategies of Protection and Defense by Multinational Corporations: Spreading the Risk and Raising the Cost for Nationalization in Natural Resources". International Organization 27 (1973), p. 273-87.

Moran, Theodore (ed.). Multinational Corporations: The Political Economy of Foreign Direct Investment. (Lexington Books, 1985)

Neumayer, Eric. Greening Trade and Investment: Environmental Protection without Protectionism. (Earth Scan, 2001)

Neumayer, Eric and Spess, Laura. "Do Bilateral Investment Treaties Increase FDI to Developing Countries?". 33 World Development 10 (2005), p. 15671585.

Newcombe, Andrew and Paradell, Lluis. Law and Practice of Investment Treaties: Standard of Treatment. (Kluwer Law International, 2009)

Nordhaus, William D. "A Review of the Stern Review on the Economics of Climate Change", "A Review of the Stern Review on the Economics of Climate". 45 Journal of Economic Literature 3 (2007), p. 686-702. 
Oi, Jean C. and Walder, Andrew G. (eds.). Property Rights and Economic Reform in China. (Stanford University Press, 1999)

Oneal, John R. "The Affinity of Foreign Investors for Authoritarian Regimes". 47 Political Research Quarterly 3 (1994), p. 565-588.

Organisation for Economic Cooperation and Development (OECD). International Investment Law: A Changing Landscape. (OECD Publishing, 2005)

Poulsen, Lauge Skovgaard. "Political Risk Insurance and Bilateral Investment Treaties: A View From Below". Columbia FDI Perspectives, No. 27, August 2, 2010

Putnam, Robert D. "Diplomacy and Domestic Politics: The Logics of Two Levels Game". 42 International Organization 3 (1988), p. 427-460.

Qian, Yingyi "The Institutional Foundations of China's Market Transition". (Stanford University Economics Department Working Paper 99-011, 1999)

Peterson, Luke Eric. "Human Rights and Bilateral Investment Treaties: Mapping the Role of Human Rights Law within Investor State Arbitration". (Rights \& Democracy (International Centre for Human Rights and Democratic Development), 2009)

Peterson, Luke Eric. "The Global Governance of FDI: Madly Off in All Directions". (Friedrich Ebert Stiftung Dialogue on Globalization Occasional Paper No. 19, 2005)

Salacuse, Jeswald W. and Sullivan, Nicholas P. "Do BITs Really Work? An Evaluation of Bilateral Investment Treaties and Their Grand Bargain," 46 Harvard International Law Journal (2005), p. 67-130.

Schelling, Thomas. The Strategy of Conflict. (Harvard University Press, 1981)

Scott, Robert E. and Stephan, Paul B. The Limits of Leviathan: Contract Theory and the Enforcement of International Law. (Cambridge University Press, 2006)

Sornarajah, M. The International Law on Foreign Investment. (Cambridge University Press, 2004)

Stigler, George J. Citizen and the State: Essays on Regulation. (University of Chicago Press, 1975)

Stern, Nicholas. "The Stern Review on the Economics of Climate Change". HM Treasury, London (2006)

Stopford, John M. "The Growing Interdependence between Transnational Corporations and Governments". Transnational Corporations 3 (1994), p. 53-76.

Tirole, Jean. “Incomplete Contracts: Where Do We Stand?". 67 Econometrica 741 (1994)

Teece, David J. "Transaction Cost Economics and the Transnational Enterprise". 7 Journal of Economic Behavior and Organization 7 (1986), p. 21-45.

Tobin, Jenifer and Rose-Ackerman, Susan. "FDI and the Business Environment in Developing Countries: the Impact of Bilateral Investment Treaties". (Yale Law \& Economics Research Paper No. 293, 2005) 
Tobin, Jenifer and Rose-Ackerman, Susan. "When BITs Have Some Bite: the Political Economic Environment for Bilateral Investment Treaties" (2006)

UNCTAD World Investment Report 2010, published 22 July 2010, http://www. unctad.org/Templates/WebFlyer.asp?intItemID=5535\&lang=1 (last access 1 August 2010)

UNCTAD World Investment Report 2009 http://unctad.org/en/docs/wir2009_ en.pdf (last access 2 August 2010)

Vachani, Sushil. "Enhancing the Obsolescing Bargain Theory: A Longitudinal Study of Foreign Ownership of U.S. and European Transnationals". 26 Journal of International Business Studies 1 (1995), p. 159-180.

Van Aaken, Anne. "International Investment Law between Commitment and Flexibility: A Contract Theory Analysis". 12 Journal of International Economic Law 507 (2009)

Vandevelde, Kenneth. "The Economics of Bilateral Investment Treaties". 41 Harvard International Law Journal 470, 490 (2000)

Vernon, Raymond. Storm over the Multinationals: The Real Issues. (Harvard University Press, 1977)

Voigt, Stefan. "How to Measure the Rule of Law". (MAGKS Papers on Economics, 2009)

Williamson, Oliver E. The Economic Institutions of Capitalism. (Free Press, 1998)

Yackee, Jason Webb. “Do BITs Really Work? Revisiting the Empirical Link Between Investment Treaties and FDI", in Sauvant, Karl P. and Sachs, Lisa. The Effect of Treaties on FDI: Bilateral Investment Treaties, Double Taxation Treaties, and Investment Flows. (Oxford University Press, 2009)

\section{News}

Diaz, Fernando Cabrera. "German investor launches ICSID case against Costa Rica over alleged expropriation of land near endangered turtle habitat". http:// www.investmenttreatynews.org/cms/news/archive/2009/12/04/ german-investor-launches-icsid-case-against-costa-rica-over-allegedexpropriation-of-land-near-endangered-turtle-habitat.aspx (last access 1 August 2010)

Diaz, Fernando Cabrera. "Philip Morris initiates arbitration against Uruguay over new labeling requirements, taxes". http://www.investmenttreatynews. $\mathrm{org} / \mathrm{cms} / \mathrm{news} /$ archive/2010/05/11/philip-morris-initiatesarbitration-against-uruguay-over-new-labeling-requirements-taxes.aspx (last access 1 August 2010)

Investment Treaty News (ITN). March 27, 2008. www.iisd.org/pdf/2008/itn_ mar27_2008.pdf (last access 25 July 2010)

Vis-Dunbar, Damon, and Nikiema, Henrique Suz.y "Do Bilateral Investment Treaties Lead to More Foreign Investment?". 30 April 2009. http:// www.investmenttreatynews.org/cms/news/archive/2009/04/30/dobilateral-investment-treaties-lead-to-more-foreign-investment.aspx (last access 3 August 2010) 
Vis-Dunbar, Damon ."Norway shelves its draft model bilateral investment treaty". 8 June 2009. http://www.investmenttreatynews.org/cms/news/ archive/2009/06/08/norway-shelves-its-proposed-model-bilateralinvestment-treaty.aspx (last access 25 July 2010).

"Bolivia Submits a Notice under Article 71 of the ICSID Convention". 16 May 2007. http://icsid.worldbank.org/ICSID/FrontServlet?requestType=Ca sesRH\&actionVal=0penPage\&PageType=AnnouncementsFrame\&From Page $=$ NewsReleases\&pageName=Announcement3 (last access 23 July 2010)

"Ecuador Submits a Notice under Article 71 of the ICSID Convention". 9 July 2009. http://icsid.worldbank.org/ICSID/FrontServlet?requestType=Ca sesRH\&actionVal=0penPage \&PageType=AnnouncementsFrame\&From Page $=$ NewsReleases\&pageName=Announcement20 (last access 23 July 2010)

"Venezuela surprises the Netherlands with termination notice for BIT; treaty has been used by many investors to "route" investments into Venezuela". 16 May 2008. http://www.iareporter.com/articles/20091001_93 (last access 23 July 2010) 